ISSN: 0213-2079 - ISSN electrónico: 2386-3889

DOI: https://doi.org/10.14201/shhmo2018401361403

\title{
TERRITORIO Y SISTEMAS DEFENSIVOS DE FRONTERA: EL PROYECTO DE ISIDRO PRÓSPERO VERBOOM PARA LAS FORTIFICACIONES DE SAN SEBASTIÁN EN 1726
}

\section{Territory and Frontier Defence Systems: The Project of Isidro Próspero Verboom for the Fortification of San Sebastian in 1726}

\author{
Víctor ECHARRI IRIBARREN \\ Universidad de Alicante \\ Correo-e: Victor.Echarri@ua.es
}

RESUMEN: La modernización de las fortificaciones de la frontera hispano-francesa fue un objetivo prioritario de la monarquía Borbónica. En 1725 Jorge Próspero Verboom, acompañado de su hijo Isidro Próspero, se estableció a Pamplona. Desde allí dirigió los proyectos de fortificación para San Sebastián, Pamplona y Fuenterrabía. Encargó a Isidro la redacción del proyecto para San Sebastián, utilizándolo como aval para sucederle en el cargo de Ingeniero General. El proyecto constaba de un total de treinta y siete planos, el más extenso de los redactados en la historia de la fortificación española. Esta investigación analiza sus aspectos técnicos. Además de las reparaciones de las brechas del sitio de 1719, Isidro Próspero Verboom reforzaba las defensas en puntos estratégicos, y establecía un ambicioso sistema de baterías en lo alto del monte Urgull. Situaba así la plaza por delante de Fuenterrabía en importancia defensiva, aunque las inversiones eran muy inferiores a las destinadas para Pamplona.

Palabras clave: San Sebastián; fortificaciones; desarrollo urbano; ingenieros militares; Verboom. 
ABSTRACT: The modernising of the fortifications on the FrenchSpanish border was a priority for the Borbon monarchs. In 1725 Jorge Próspero Verboom, accompanied by his son Isidro Próspero, moved to Pamplona. From there he directed the projects for the fortification of San Sebastián, Pamplona and Fuenterrabía. He entrusted Isidro with drawing up the project for San Sebastián, using this as a way of ensuring that he would succeed him in the post of Engineer General. The project consisted of thirty seven plans, the most extensive of any drawn up in the history of Spanish fortifications. This research analyses the technical aspects of it. In addition to repairing the breaches in the siege of 1719, Isidro Próspero Verboom strengthened the defences at strategic points, and established an ambitious system of batteries at the top of Mount Urgull. In this way he gave the square in front of Fuenterrabía an important defensive role, although the investment was much less than that destined for Pamplona.

Key words: San Sebastián; Fortifications; Urban Development; Military Engineers; Verboom.

\section{INTRODUCCIÓN}

La transformación en España de las antiguas fortalezas medievales hacia el sistema abaluartado fue un proceso complejo ${ }^{1}$. Ciertamente todos los reinos europeos debieron afrontar nuevos escenarios, nuevos requisitos técnicos, y dificultades de financiación. Pero las peculiaridades geográficas, la estrategia de alianzas y los conflictos bélicos y amenazas exteriores adoptaron rasgos singulares durante el reinado de los Reyes Católicos y la dinastía de la Casa de Austria. La concepción defensiva de la Península se basó en un cuidadoso estudio de las plazas de costa susceptibles de invasión y posterior avance hacia el interior-denominando a algunas de ellas «llaves de España»- y la defensa de fronteras con Francia y Portugal ${ }^{2}$. En el primer caso preocupaba la amenaza turca y los berberiscos. En el caso de las

1. Cfr. Tzonis, A. y Lefaivre, L.: «El bastión como mentalidad», en Seta, C. De; Le Goff, J. (eds.): La ciudad y las murallas. Madrid, 1991, p. 321. La invención del bastión fue el resultado de una evolución gradual a lo largo de varias décadas, con marcados hitos puntuales, preferentemente desarrollados en Italia. Cfr. Rocolle, P.: 2000 ans de fortification française. Vol. 2, Du 16e siècle au mur de l'Atlantique. París, 1989, pp. 115-121.

2. Como bien señala Quatrefages, de fronteras adentro, por razones logísticas, no pudo efectuarse una renovación de la fortificación acorde con las exigencias defensivas modernas. Cfr. Quatrefages, R.: «La fortificación en España durante el Renacimiento (II)», Ejército, 1984, p. 74. 
fronteras, la de Portugal podía dominarse con una superioridad de fuerzas y unas pocas plazas fuertes como Badajoz, Ciudad Rodrigo o Puebla de Sanabria. La de Francia era fuerte por naturaleza, con los Pirineos ejerciendo de obstáculo para introducir un tren de artillería. Únicamente a través del Rosellón y la Cerdaña cabía la invasión, como sucedería en ocasiones por la difícil situación política de Cataluña. Para ello se reforzarían plazas como Puigcerdá, Rosas, Castelciudad, Lérida, Gerona o Barcelona. Y por la parte occidental, los abruptos puertos del pirineo navarro por la parte de Baztán, Quinto Real, Salazar o Roncal, obligaban a procurar el acceso a Castilla por Fuenterrabía y San Sebastián, teniendo en cuenta que Pamplona ejercía de centro logístico para la organización defensiva.

Estas tres plazas fuertes serían continuamente revisadas y reforzadas, configurando entre ellas un verdadero sistema de mutuo apoyo. Los Reyes Católicos iniciaron la modernización de San Sebastián y Fuenterrabía con la construcción de pequeños bastiones capaces de alojar artillería ${ }^{3}$ (Fig. 1). Pronto Pamplona, tras la anexión a Castilla en 1512, albergaría un moderno castillo que introducía las técnicas defensivas más vanguardistas. En la década de 1520 se adoptarín baluartes en las esquinas del recinto, y en los años 30 se construirían baluartes de mucha mayor envergadura en puntos estratégicos, en forma de corazón en Fuenterrabía -denominados de la Magdalena y San Nicolás nuevo- y Pamplona -el baluarte de San Llorente-, del que ha quedado una valiosa representación (Fig. 2). En San Sebastián, que en el argot de la época se denominaría «llave de Francia» por su importancia defensiva de la frontera noroccidental hispano-francesa, se iniciaría en 1542 el frente que miraba hacia el interior, en la conexión del monte Urgull con el interior, a lo largo de la desembocadura del río Urumea. Se construyó entonces por orden de Carlos V, que tres años antes había visitado la ciudad, el cubo Imperial, que abandonaba la forma de corazón por otra de flecha. Sería el elemento fuerte capaz de de alojar numerosas piezas de artillería, y que batía cualquier aproximación del enemigo desde el sur. También se incorporaron dos bastiones, denominados del Ingente y del Gobernador, a cada lado del cubo Imperial, en contacto con el mar. Se formaba así el denominado frente real ${ }^{4}$ (Fig. 3).

3. Cfr. Astiazaráin Achábal, M. I.: «El Patrimonio Militar de Hondarribia: el Castillo de Carlos V y las Murallas», en Orella Unzué, J. L.: Historia de Hondarribia. Hondarribia, 2004, pp. 482-484; Fernández Antuña, C. M.: Murallas de Hondarribia. De la cerca medieval al recinto abaluartado. Hondarribia, 2003, pp. 136-140.

4. Se tiene conocimiento de este frente por la documentación gráfica que nos ha llegado, y por algunas prospecciones arqueológicas. Cfr. Fernández AntuÑa, C. M. y Ayerbe Irízar, M.: «Sondeos arqueológicos en el Boulevard (1993): El Frente de Tierra de las fortificaciones de San Sebastián (s. XVI)», Boletín de Estudios Históricos sobre San Sebastián, 28, 1994, pp. 741-766. 
Pero a pesar de la introducción de planteamientos innovadores -la Corona de España contó con los más reputados y experimentados ingenieros militares de la época, importados principalmente de Italia- lo cierto es que hasta bien entrado el siglo xvi convivieron en España fortalezas medievales, renacentistas y reformadas. Bajo el reinado de Carlos V siguieron reforzándose nuestras tres fortificaciones fronterizas, además de realizarse extraordinarias obras de fortificación en ciudades costeras como Mallorca, Cádiz, Gibraltar, Málaga y La Coruña ${ }^{5}$.

Una vez que Felipe II llegó al poder se produjeron grandes cambios en el ámbito de la fortificación ${ }^{6}$, entre los que cabe reseñar el esfuerzo del monarca por potenciar la formación técnica y científica de sus súbditos ingenieros, creando la Academia de Matemáticas de Madrid. Así surgieron ingenieros expertos y tratadistas formados en España. Pero Felipe II continuó importando de sus dominios en Italia ingenieros prestigiosos para las fortificaciones de la Corona, como los Fratín ${ }^{7}$, Tiburcio Spannocchi ${ }^{8}$, Juan Bautista Antonelli en las fortificaciones de la Península -entre ellas San Sebastián- y las posesiones de Ultramar; y Francesco de Marchi y Francesco Paciotto, proyectistas de algunas fortificaciones construidas en Italia y Flandes ${ }^{9}$, como las ciudadelas de Turín y Amberes. A finales de siglo se daría un nuevo impulso a la defensa de Fuenterrabía, San Sebastián y Pamplona. Tras los informes de Antonelli y Jacobo Palear, se dio prioridad estratégica a Pamplona con la construcción en 1571 de una ciudadela pentagonal basada en el modelo de la de Amberes, y tres amplios bastiones en el recinto. En las otras dos plazas se dispuso un baluarte de última generación, denominado en ambos casos de San Felipe, proyectados por el Fratín y ajustados poco después por Spannocchi.

Durante el siglo xvir la hegemonía hispana en materia de fortificación cayó en declive, mientras que en los Países Bajos y Francia se produjo en este campo un relevante desarrollo técnico y científico. Se reforzaron los frentes bastionados mediante revellines, hornabeques, coronas o tenazas, en un constante pulso con los avances tecnológicos que experimentó la artillería. El ataque y la defensa de

5. Cfr. Capel, H.: «Los ingenieros militares y el sistema de fortificación en el siglo XvinI», en CÁmara Muñoz, A. (coord.): Los ingenieros militares de la Monarquía Hispánica en los siglos XVI y XVII. Madrid, 2005, p. 232.

6. CÁmAra MuÑoz, A.: «Murallas para la guerra y para la paz. Imágenes de la ciudad en la España del siglo XVI», Espacio, Tiempo y Forma, Serie VII, $H^{\text {a }}$ del Arte, t. 6, 1993, pp. 149-174.

7. Cfr. Viganò, M.: "El fratin mi ynginiero". I Paleari Fratino da Morcote ingegneri militari ticinesi in Spagna (XVI-XVII secolo). Bellinzona, 2004.

8. Cámara Muñoz, A.: «Tiburzio Spannocchi, Ingeniero Mayor de los reinos de España», Espacio, Tiempo y Forma, Serie VII, 2, 1988, pp. 77-90.

9. Bragard, Ph.: Dictionnaire biographique des ingénieurs des fortifications: Pays-Bas espagnols, principauté de Liège, Franche-Comté, 1504-1713. Namur, 2011. 
plazas era una disciplina extremadamente compleja. A la coordinación logística había que añadir la gestión de las tropas, los trabajos de zapa, minas y contraminas, y un largo etcétera de operaciones que era preciso sistematizar en aras de hacer exitosa una campaña. Sébastien le Prestre Vauban ${ }^{10}$ fue el genio que racionalizó la guerra de sitios en el último tercio de siglo. Podría resumirse toda esta evolución proyectual en tres fases. La primera acometió la transformación de los viejos recintos medievales en recintos abaluartados, capaces de alojar artillería y ocultar casamatas. La segunda fase consistió en la construcción de revellines, hornabeques o tenazas delante de los frentes bastionados. Y la tercera se caracterizó por una serie de proyectos que introducían fuertes exteriores y reductos avanzados en lugares estratégicos ${ }^{11}$.

En este escenario desarrolló su labor profesional el ingeniero militar Jorge Próspero Verboom, padre del protagonista de esta investigación. Su formación inicial con su padre Cornelio, con Sebastián Fernández de Medrano ${ }^{12}$ en la Real Academia Militar de Bruselas, posteriormente con Menno van Coehoorn en las campañas de los Países Bajos de 1691, y finalmente en la Guerra de Sucesión con Vauban, hacen de él un exponente único, si tenemos en cuenta además que posteriormente sería Ingeniero General en España bajo el reinado de Felipe $\mathrm{V}^{13}$. Jorge Próspero se encargaría de la formación de su hijo Isidro Próspero, llamado

10. Vauban fue un verdadero genio que sistematizó la guerra de sitios y estableció sistemas defensivos admirados en toda Europa. El sistema centralizado francés de Luis XIV se adoptó también en la formación de los ingenieros militares, quienes al intervenir en conflictos bélicos, aplicaron las máximas de Vauban en numerosas plazas europeas. La bibliografía sobre la figura y obras de Vauban es muy amplia. Cfr. Faucherre, N.: Places fortes, bastion du pouvoir. París, 1989. Sobre lo que supuso Vauban y su influencia en la fortificación de finales del XVII y el xviII, véase Warmoes, I.: «Vauban et l'art de la fortification», en Warmoes, I. (coord.): Vauban, bâtisseur du Roi-Soleil. París, 2007, pp. 190-197. Sobre la influencia en España, cfr. Совоs Guerra, F.: «La fortificación española en los siglos XVII y xviII: Vauban sin Vauban y contra Vauban», en Silva Suárez, M. (ed.): Técnica e ingeniería en España. El siglo de las luces. Vol. II, Madrid, 2005, pp. 469-520.

11. Echarri Iribarren, V.: Las Murallas y la Ciudadela de Pamplona. Pamplona, 2000, pp. 197-222.

12. Sobre este ingeniero véase: Llave y García, J. de la: «Don Sebastián Fernández de Medrano, como escritor de fortificación», Memorial de Ingenieros, Madrid, 33:15, 1878; Rodríguez Villa, A.: «Don Sebastián Fernández de Medrano. Director de la Real Academia Militar de Bruselas (1646-1705)», Revista Contemporánea, Madrid, 147, 1882. Para conocer mejor sus aportaciones técnicas, cfr. FernÁndez DE Medrano, S.: El arquitecto perfecto en el Arte Militar: Dividido en cinco libros. El $1^{\circ}$ contiene la fortificación regular e Irregular a la Moderna... Bruselas, 1700.

13. Fue nombrado por Felipe V Ingeniero General en 1710 a instancias de la recomendación hecha por Vauban a Luis XIV. Cfr. Muñoz Corbalán, J. M.: Los Ingenieros Militares de Flandes a España (1691-1718). 2 Tomos. Madrid, 1993, p. 63. 
VÍCTOR ECHARRI IRIBARREN

TERRITORIO Y SISTEMAS DEFENSIVOS DE FRONTERA: EL PROYECTO DE ISIDRO PRÓSPERO VERBOOM PARA LAS FOSTIFICACIONES DE SAN SEBASTIÁN EN 1726

a ser su sucesor en el cargo de Ingeniero General. El proyecto general para las fortificaciones de San Sebastián que redactaría Isidro en 1726 jugaría un importante papel en el proceso de preparación del candidato.

\section{Las fortificaciones abaluartadas de San Sebastián}

Conocemos la evolución histórico-constructiva de las fortificaciones de Pamplona gracias a algunos trabajos relativamente recientes ${ }^{14}$, y lo mismo puede decirse de las de Fuenterrabía ${ }^{15}$, aunque con algunas lagunas, pero se han estudiado poco en este sentido las fortificaciones de San Sebastián. Destacan los trabajos de Porras Gil, Sáez García, y Olavide, Albarellos y Vigón, aunque su objetivo se aleja del análisis técnico de los proyectos y su contextualización ${ }^{16}$. Se expondrá aquí un

14. Sobre las fortificaciones de Pamplona en la época medieval y su importancia estratégica, cfr. Martinena Ruiz, J. J.: La Pamplona de los Burgos y su evolución urbana. Pamplona, 1974. Para un conocimiento del proceso histórico-constructivo, véase Echarri IrIbarren, V.: Las Murallas y la Ciudadela de Pamplona. Pamplona, 2000; Echarri Iribarren, V.: «Jorge Próspero de Verboom General Project for the Fortifications of Pamplona in 1726», SGEM 2014 International Multidisciplinary Conferences on Social Sciences and Arts, 1-9 September 2014, Albena, 2014, pp. 897-908. Para su consideración en el siglo xIx y posterior derribo de algunas partes de las murallas, cfr. Elizalde Marquina, E.: Pamplona plaza fuerte. 1808-1973. Del derribo a símbolo de identidad de la ciudad. Pamplona, 2012.

15. Cfr. entre otras: Cobos Guerra, F. y Castro Fernández, J. J. de: «Diseño y desarrollo técnico de las fortificaciones de transición españolas», en Hernando Sánchez, C. J. (coord.): Las Fortificaciones de Carlos V. Madrid, 2000, pp. 218-243; Cámara Muñoz, A.: «La Corona de Castilla», en Hernando Sánchez, C. J. (coord.): Las Fortificaciones de Carlos V. Madrid, Ministerio de Defensa; Asociación Española de Amigos de los Castillos; Sociedad Estatal para la Conmemoración de los Centenarios de Felipe II y Carlos V, DL, 2000, pp. 415-439; Astiazaráin Achábal, M. I.: «El Patrimonio Militar de Hondarribia: el Castillo de Carlos V y las Murallas», en Orella Unzué, J. L.: Historia de Hondarribia. Hondarribia, 2004, pp. 477-551; Fernández Antuña, C. M.: Murallas de Hondarribia. De la cerca medieval al recinto abaluartado. Hondarribia, 2003; Echarri Iribarren, V. y Yáñez Pacios, R. T.: «Bastión y ciudad: Los proyectos para las fortificaciones de Fuenterrabía a finales del siglo XvI», Tiempos Modernos. Revista Electrónica de Historia Moderna, 8:32, 2016, pp. 88-124.

16. Cfr. Porras GiL, C.: La Organización Defensiva Española en los siglos XVI-XVII. Desde el río Eo hasta el Valle de Arán. Valladolid, 1995, pp. 151-205, que publicó las figuras 1, 3 y 6 de esta investigación; Olavide, J., Albarellos, B. y Vigón, J.: San Sebastián. Historia de sus fortificaciones. Siglos XVI y XVII. El sitio de 1813. San Sebastián, 1963; SáeZ García, J. A.: Gotorlekuak Gipuzkoan XVI-XIX mendean. Fortificaciones en Guipúzcoa siglos XVI-XIX. Donostia, 2002; SÁEz García, J. A.: Viejas piedras: fortificaciones guipuzcoanas. San Sebastián, 2000; Roldán, J. M., Sáez, J. A., Piñeiro, J. G., Orella J. L. y Aramburu, J. M.: Documentos cartográficos históricos de Gipuzkoa: I Servicio Geográfico del Ejército. San Sebastián, 1994, en que se publicaron las figuras 8 a 20 y 23 de este trabajo; Gómez Piñeiro, F. J. y Sáez García, J. A.: Documentos cartográficos Históricos de Gipuzkoa: II Servicio Histórico Militar. San Sebastián, 1999, que publicó las figuras 7 y 22; SÁEz GARcía, J. A.: «Fortificaciones liberales

Ediciones Universidad de Salamanca / @o@ Stud. his., H. ${ }^{a}$ mod., 40, n. 1 (2018), pp. 361-403 
elenco de los hitos más importantes de su evolución, si bien no se procurará una caracterización de todos los elementos de las fortificaciones, que requerirían un amplio estudio que excede las pretensiones de este artículo.

Aunque se desconocen los hechos referentes a la fundación de San Sebastián, las primeras noticias apuntan a la existencia del monasterio situado en el barrio del mismo nombre. En los siglos XI y XII desarrolló un importante influjo mercantil que propició el desarrollo social y administrativo de la población de la zona. Este desarrollo sufrió un importante impulso bajo el reinado del monarca navarro Sancho el Sabio, que la dotó hacia 1180 de un fuero similar a los dispuestos en Jaca o Estella, con un creciente proceso de repoblación. Se precisaba potenciar el comercio de las lanas navarras y aragonesas a través de un puerto comercial. El núcleo urbano inicial se desplazó así hacia la falda del monte Urgull, dotado de un recinto amurallado que protegía la actividad portuaria. Al igual que sucediera con núcleos de población situados en lugares estratégicos de costa y de frontera ${ }^{17}$, San Sebastián contó desde su primitiva fundación con unas murallas medievales dominadas por la escarpada elevación del monte Urgull. Se trataba de una pequeña colina de unos 700 metros de diámetro y cota de 60 metros sobre el nivel del mar. Al quedar adentrada en el mar hacia el norte, constituía un lugar fuerte de indudable valor estratégico, acentuado por lo escarpado de sus laderas hacia el mar, especialmente hacia el este.

La planta delimitada por la fortificación baja, que albergaba el núcleo urbano, era aproximadamente cuadrada. Limitaba al norte con el monte Urgull, al sur con los arenales del Tómbolo y, al este y oeste por el mar (Fig. 1). Las casas medievales eran en su generalidad de madera, que fue en gran medida la causa de los numerosos incendios sufridos por la ciudad. Tras el acaecido en 1489 se generalizó el uso de la piedra y argamasa en las construcciones en sustitución de la madera. Además de esta fortificación «baja», se erigió en el siglo XII una fortificación «alta» sobre el monte Urgull. Inicialmente estaba formada por un pequeño castillo situado en la parte más elevada del monte, denominado de la Mota ${ }^{18}$. Tenía, al parecer, planta cuadrada, con torreones en las esquinas y muros almenados de unos siete metros

en el entorno de San Sebastián en la última Guerra carlista», Boletín de Estudios Históricos sobre San Sebastián, 35, 2001, pp. 255-327; Mexía Carrillo, F.: El castillo de Santa Cruz de la Mota y las murallas de la Plaza de San Sebastián. San Sebastián, 1979; Artola, M.: Historia de Donosita-San Sebastián. San Sebastián, 2004, pp. 110-114 y 183-187.

17. Mantecón Movellán, T. A. y Truchuelo García, S.: «Las frontera exteriores e interiores de la Monarquía Hispánica: perspectivas historiográficas», Historia Crítica, 59, 2016, pp. 25-28.

18. Porras Gil, C.: La Organización Defensiva Española..., op. cit., p. 152. 
VÍCTOR ECHARRI IRIBARREN

TERRITORIO Y SISTEMAS DEFENSIVOS DE FRONTERA: EL PROYECTO DE ISIDRO PRÓSPERO VERBOOM PARA LAS FOSTIFICACIONES DE SAN SEBASTIÁN EN 1726

de altura. Contaba con una pequeña torre del homenaje y con una barbacana que protegía la puerta, situada en la cara oeste.

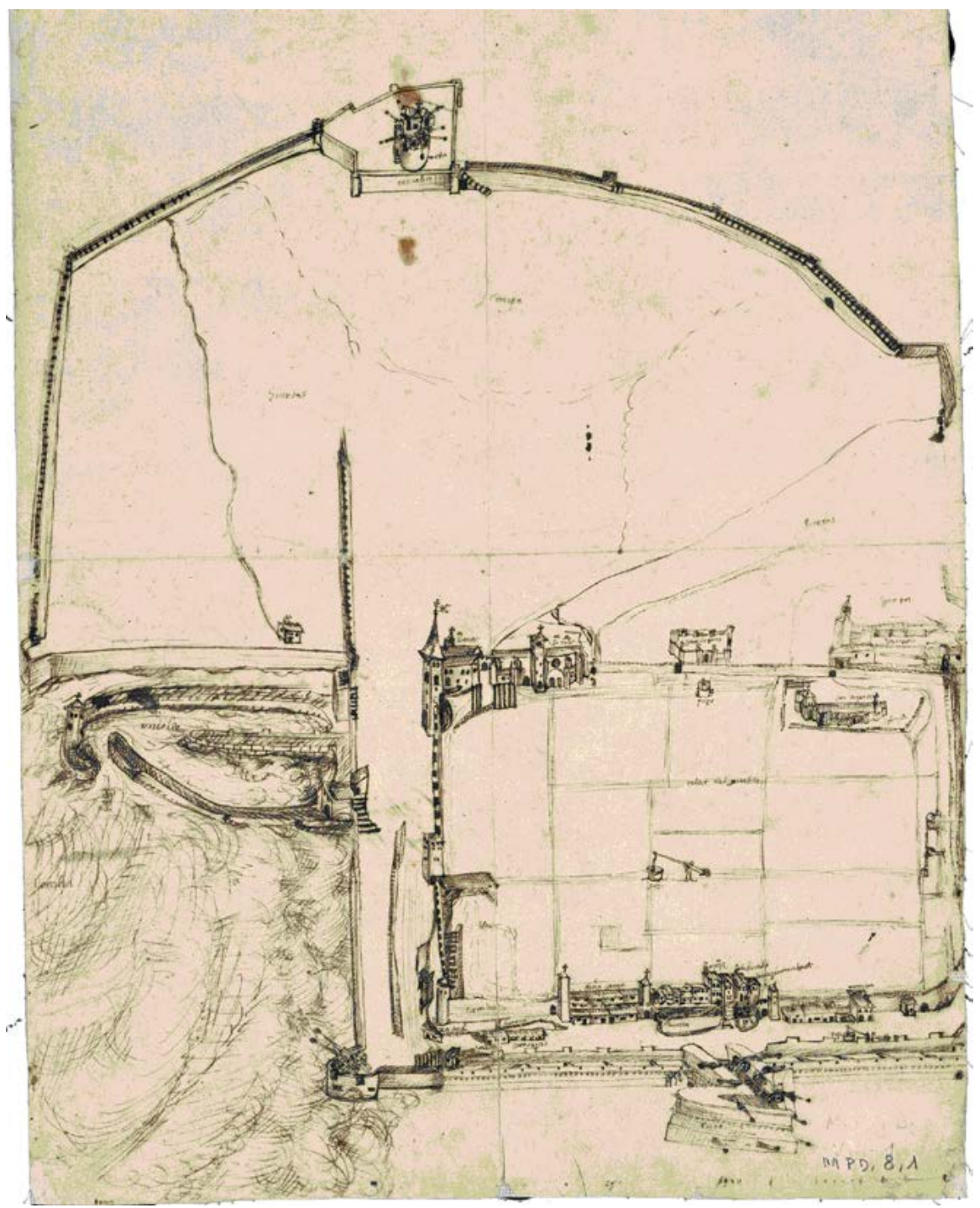

Figura 1. Plano de la ciudad de San Sebastián y de su recinto amurallado. Anónimo. H. 1552. Ministerio de Educación, Cultura y Deporte (MECD). Archivo General de Simancas [en adelante AGS]. M.P. y D. VIII-01.

Ediciones Universidad de Salamanca / 
La muralla medieval dejó de ser operativa, al igual que el parque de fortificaciones de la Península, tras la aplicación de la artillería en la guerra de sitios. A comienzos del siglo xvi, la creciente importancia estratégica de San Sebastián, obligó a los soberanos a mantener y modernizar sus fortificaciones con la aplicación de pequeños bastiones en el frente sur del recinto. Para ello contaron con los más prestigiosos ingenieros militares de la época. Se levantó la muralla nueva, conocida como la de los Reyes Católicos, que dejaba alrededor un amplio margen de terreno para permitir el posterior ensanche de la villa. Comenzó a restaurarse también el ruinoso castillo que dominaba el monte Urgull. Las primeras reformas a este recinto se llevaron a cabo promovidas por Carlos V en 1520, y continuadas por el proyecto que elaboró el prestigioso Gabriel Tadino de Martinengo, Prior de Barleta en 1523. Se centraba principalmente en la fachada del Arenal, y en los muros de comunicación del castillo de la Mota con la ciudad ${ }^{19}$. En 1542 se comenzó a fortificar el sector oriental-que sería siempre el más vulnerable- construyendo un lienzo de muralla a lo largo de la desembocadura del río Urumea. En Pamplona y Fuenterrabía se habían acometido similares transformaciones, siempre con cierto adelanto y supremacía sobre San Sebastián ${ }^{20}$. Hacia 1535, por ejemplo, se habían construido algunos baluartes en forma de corazón, impulsados por los ingenieros italianos Giacomo Castrioto y Girolamo Maggi ${ }^{21}$. En el caso de San Sebastián se acometería en 1535 la construcción de un cubo en el castillo de la Mota y otro en la puerta del muelle ${ }^{22}$, pero acabaría prevaleciendo la construcción en 1542 del cubo Imperial, llamado así en honor de Carlos V. El monarca había visitado San Sebastián tres años antes, en 1539, y había dispuesto que no se reparara en gastos a la hora de fortificar la villa. Fue enviado a tal efecto el

19. Porras Gil, C.: La Organización Defensiva Española..., op. cit., pp. 155-162.

20. En el caso de Fuenterrabía, por ejemplo, los Reyes Católicos construyeron sobre la antigua torre defensiva un castillo, que Carlos $\mathrm{V}$ mandó ampliar y restaurar posteriormente. Astiazaráin Achábal, M. I.: «El Patrimonio Militar de Hondarribia: el Castillo de Carlos V y las Murallas», op. cit., pp. 477-482. En Pamplona la construcción del castillo de Santiago fue un hito en la fortificación peninsular del momento. Cfr. Echarri Iribarren, V.: Las Murallas y la Ciudadela de Pamplona. Pamplona, 2000, pp. 90-92.

21. En Fuenterrabía se hicieron los baluartes de la Magdalena y San Nicolás nuevo. Cfr. Fernández Antuña, C. M.: Murallas de Hondarribia..., op. cit., pp. 156-165; Echarri IribarRen, V. y Yáñez Pacios, R. T.: «Bastión y ciudad: Los proyectos para las fortificaciones de Fuenterrabía a finales del siglo XVI», op. cit., pp. 88-124. En Pamplona se trató del baluarte de san Llorente. Echarri Iribarren, V.: Las Murallas y la Ciudadela de Pamplona. Pamplona, 2000, pp. 100-102.

22. Cédula de 12 de agosto de 1535 aprobando el asiento hecho para la construcción de un cubo en el castillo de la Mota y puerta del muelle. Archivo General Militar de Madrid [en adelante AGMM]. Colec. Aparici, t. I, 1-5-1, p. 78. 
Capitán Luis Pizaño ${ }^{23}$, que probablemente sería el autor del diseño del cubo ${ }^{24}$. Este tenía ya una forma diferente, una vez puesta en cuestión la original forma de corazón. Se disponía en forma de flecha, con amplias baterías en los lados de su punta que batían hacia el mar a derecha e izquierda, protegiendo de un posible acceso desde el interior (Fig. 3). Se generaba así un nuevo conjunto bastionado por delante del medieval, que se completaría en su parte sur, mientras que en las partes este y oeste carecerían de bastiones.

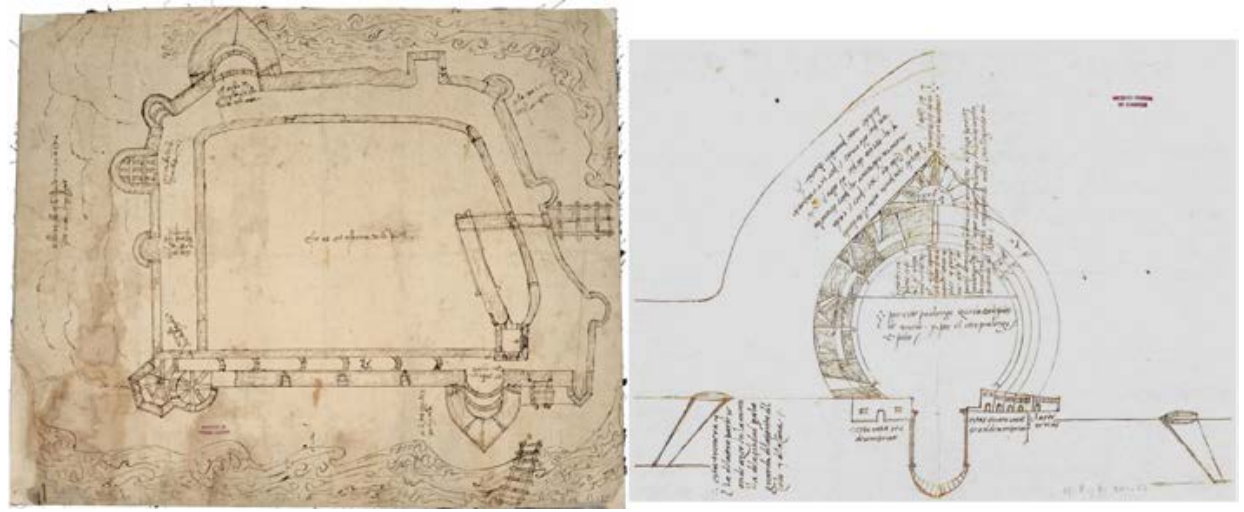

Figura 2. Las fortificaciones de Fuenterrabía hacia 1535. Anónimo. MECD. AGS. M.P. y D. XIII-55 (izquierda). Traça de la fortaleza de Pamplona. Bastión de San Llorente. Anónimo. H. 1538. AGS. M.P. y D. XIII-55 (derecha).

Bajo el reinado de Felipe II se acometieron algunas obras de importancia. En 1567 se realizaron obras de ampliación en el espacio que se asentaba en el llamado postigo de San Nicolás, junto a la Zurriola. También se ensanchó el baluarte sur del lienzo oriental, llamado del Gobernador. Había quedado obsoleto e incapaz para albergar las modernas piezas de artillería. Dominaba la desembocadura del Urumea. Algo similar había sucedido en Fuenterrabía y Pamplona, pero en aquellas plazas las obras de ampliación se acometieron casi dos décadas antes. Tras la visita de Juan bautista Antonelli a las plazas de la frontera ${ }^{25}$, había encargado

23. Olavide, J., Albarellos, B. y Vigón, J.: San Sebastián. Historia de sus fortificaciones. Siglos XVI y XVII. El sitio de 1813. San Sebastián, 1963, pp. 23-27.

24. Porras Gil, C.: La Organización Defensiva Española..., op. cit., pp. 165-166.

25. Discurso de Juan Bautista Antonelli sobre la defensa de la frontera de Navarra y de la de Guipúzcoa. 6 de octubre de 1569. AGMM. Colec. Aparici, t. X, 1-5-10, pp. 26-42. 
Felipe II al prestigioso ingeniero Jacobo Palear Fratín, que desde 1571 se encontraba en Pamplona, que hiciera reconocimiento e informe de las fortificaciones. Y éste decidió en 1574, al igual que dispondría para Fuenterrabía, un baluarte de gran escala en el punto más importante de la defensa, llamado del Ingente, que posteriormente se llamaría de San Felipe. Además previó reforzar las defensas del castillo, y construyó una nueva plataforma para seis cañones, denominada de la Vitoria, con la que se defendería la entrada al puerto del Urumea ${ }^{26}$. Para Pamplona determinó en 1571 la necesidad de construir una ciudadela pentagonal, la primera que se levantaría en España, con la que garantizar la defensa y sujetar la ciudad y el reino de Navarra ${ }^{27}$. Se convertía definitivamente en el enclave logístico de la defensa de la frontera noroccidental con Francia.

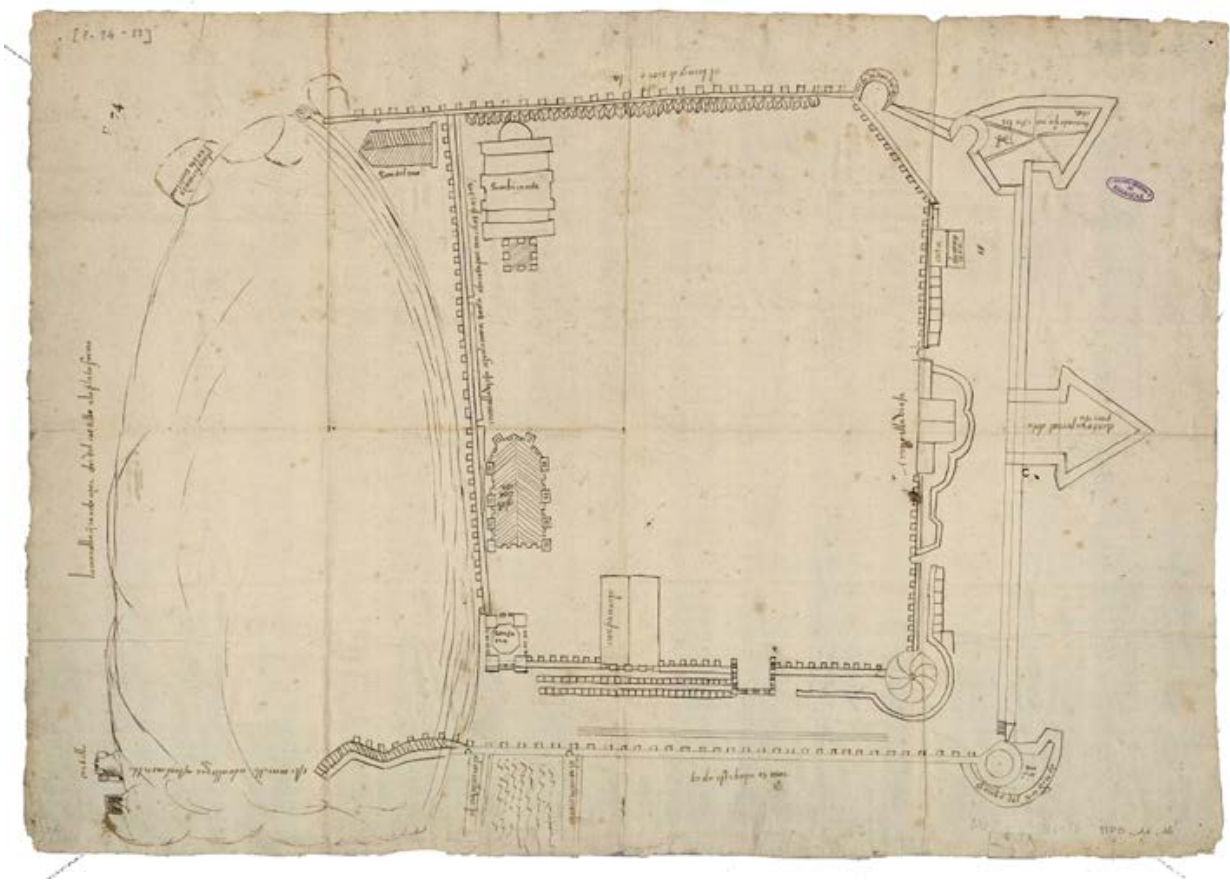

Figura 3. Plano del frente real o de Carlos V en San Sebastián. Anónimo. s.f. MECD. AGS. M.P. y D. XI-16.

26. Porras Gil, C.: La Organización Defensiva Española..., op. cit., pp. 176-177.

27. Echarri Iribarren, V.: Las Murallas y la Ciudadela de Pamplona. Pamplona, 2000, pp. 137-156. 
Poco después, en 1595, el rey solicitó a su ingeniero mayor, el italiano Tiburcio Spannocchi, que estudiara propuestas de fortificación para las tres plazas, una vez estudiados los proyectos del Fratín, que estaban en ejecución ${ }^{28}$. Estas construcciones formaban parte de un proyecto defensivo de gran envergadura, que contemplaba la construcción de modernas fortalezas a todo lo largo de la cadena pirenaica, desde el Bidasoa hasta la parte oriental de Cataluña. Las ciudadelas de Pamplona y Jaca, esta última proyectada por Spannocchi en 1592, y las fortificaciones de Perpiñán, eran los hitos más representativos y puntos neurálgicos del sistema defensivo territorial ${ }^{29}$. Spannocchi analizó las propuestas del Fratín para San Sebastián, y ratificó la importancia de la construcción del baluarte del Ingente. Era partidario, al igual que el Fratín, de no fortificar la villa sino el castillo, ya que era difícil de sitiar y minar ${ }^{30}$. Para ello diseñó una ciudadela en la Mota, del que no nos ha quedado información gráfica ni técnica ${ }^{31}$. Sin embargo determinó la ampliación de la villa y del baluarte oeste del frente sur. La razón principal era que desde el castillo se batía mal el puerto y la ciudad por la fuerte pendiente del monte Urgull. Las obras avanzaron con lentitud, y se aceleraron al compás de los conflictos bélicos ${ }^{32}$. En

28. El 24 de noviembre de 1574 el rey ordenaba que se construyera lo trazado por el Fratín, después de escuchar las opiniones, entre otros, del duque de Alba, Vespasiano Gonzaga, el Prior de Barleta y el propio Jacobo Palear Fratín. AGMM. Colec. Aparici, t. I, 1-5-1, pp. 86-87.

29. Cfr. Informe para S.M. del comendador Tiburcio Spannocchi sobre las fortificaciones de España. Valladolid, 26 de febrero de 1605. Aparici, t. XI, 1-5-11, pp. 2-14.

30. «... la conservación de aquella plaza es fortificar la Mota en la forma que Tiburcio la invia trazado que considerandolo todo es lo mas conveniente y a mi parecer sin que se le pueda ofender mediante el sitio que la montaña tiene porque con el altura que queda la muralla no se puede temer valerla y menos ser sitiada por ser toda piedra y peña y cuando el enemigo tomase la Villa quedara tan sujeta a la montaña que en ningun caso le podia sustentar la entrada de la mar y el muelle...». Carta de D. Juan Velázquez sobre el proyecto de Spannocchi sobre las fortificaciones que deben hacerse en Guipúzcoa. 23 de febrero de 1595. AGMM. Colec. Aparici, t. I, 1-5-1, pp. 89-94.

31. «En la fortificacion de San Sebastián después de largas conferencias y haber reconocido esta plaza muchos Yngenieros y personas, y últimamente el Condestable de Castilla, que fue a Inglaterra con asistencia del Comendador Tiburcio se acordo se hiciese una Ciudadela». El estado en que se hallan las fortificaciones de la costa de España. Anónimo. AGMM. Colec. Aparici, t.XI, 1-5-11, p. 45.

32. Como refiere Sáez, «La rebelión de Flandes en 1626 tuvo consecuencias directas sobre San Sebastián. Aparte de los ataques que las naves donostiarras tenían que soportar por parte de los independentistas flamencos y sus aliados holandeses cuando faenaban en los caladeros del Atlántico, un clima de paranoia se había apoderado de la Corona, aislándola cada vez más del continente europeo. Rodeada de enemigos reales o imaginarios, la monarquía española optó por la política del atrincheramiento y San Sebastián, principal bastión del sistema defensivo en la frontera septentrional, vio incrementarse todavía más sus fortificaciones». Sáez García, J. A.: Gotorlekuak Gipuzkoan XVI-XIX..., op. cit., pp. 14-21. 
1610 el ingeniero Gerónimo de Soto, que sucedería a Spannocchi tras su muerte en 1606, realizó un proyecto de ciudadela en el Urgull, del que no ha quedado información ${ }^{33}$. También prosiguió con la ampliación y modernización del cubo o baluarte del Ingente.

Durante la guerra con Francia (1635-1659) se finalizaría el baluarte y se reforzarían las defensas, tanto en el castillo de la Mota $^{34}$ como en el frente sur. En este tiempo de guerra se comisionó a los ingenieros Marco Antonio Gandolfo, Pedro Texeira y Gerónimo de Soto, que había sucedido en el cargo a Spannocchi, para realizar reconocimientos de las plazas de la frontera ${ }^{35}$, y proyectos en Fuenterrabía, San Sebastián y Pamplona. Gerónimo de Soto, en su reconocimiento del 2 de junio de 1636, incidía en el carácter fuerte del entorno, con el monte Urgull inexpugnable, y la ciudad en su falda, a la que solo se podía atacar desde la lengua de tierra. Desde el mar era imposible imposible atracar debido a las baterías existentes, y la isla de Santa Clara dominando el acceso desde el oeste. Así se decidió acometer una obra de fortificación delante del frente sur, en el que los lienzos del siglo pasado, con el cubo Imperial presidiendo, eran excesivamente elevados y fáciles para abrir brecha. Los tres ingenieros plantearon un nuevo frente, con amplios baluartes bajos delante del Ingente y del Gobernador, y un gran revellín ${ }^{36}$, además de un amplio foso y un glacis hacia el sur (Fig. 4). Otro foso separaba esta construcción del antiguo frente ${ }^{37}$. Ese fue el parecer de Soto, mientras que Gandolfo ${ }^{38}$, poco después, en 1638,

33. Memorial de La ciudad sobre el proyecto de Ciudadela en la Mota. 13 de marzo de 1610. AGMM. Colec. Aparici, t. XI, 1-5-11, pp. 84-85.

34. Las obras más importantes se llevaron a cabo en el castillo de la Mota que, posiblemente, a causa de su notable escarpadura, no poseía baluartes ni cubos. Cfr. SÁEz GARcía, J. A.: Viejas piedras: fortificaciones guipuzcoanas. San Sebastián, 2000, pp. 82-87.

35. Reconocimiento de La frontera y señorío de Navarra, por los ingenieros Pedro Tejeira Albornoz y Marco Antonio Gandolfo. 15 de mayo de 1636. AGMM. Colec. Aparici, t. XI, 1-5-11, pp. 185-212.

36. Pereda, F. y Marías, F.: «De la cartografía a la corografía: Pedro Texeira en la España del Seiscientos», Ería, 64-65, 2004, pp. 129-157

37. «Relaçión de algunos discursos tocantes a la defensa de España». Pedro Teixeira, Marco Antonio Gandolfo y Gerónimo de Soto. En San Sebastián, 31 de marzo de 1636. Biblioteca Foral de Vizcaya. VMSS-249; Reconocimientos de la frontera y plaza de Fuenterrabía. AGMM. Copia Aparici, t. XI. 1.5.11, pp. 185-218; pp. 252-260.

38. En ese mismo año de 1638, Marco Antonio Gandolfo fue el encargado de realizar un extenso informe sobre la estrategia que debía adoptarse en la guerra contra Francia. Cfr. JIMÉNEZ Moreno, A.: «Opciones estratégicas de la Monarquía Española a comienzos de la guerra contra Francia (1635-1638): la propuesta de Marco Antonio Gandolfo», Chronica Nova, 38, 2012, pp. 177-202. 
decidió modificar las propuestas diseñando un hornabeque, con un revellín en su frente, en sustitución de los baluartes bajos y el revellín ${ }^{39}$.

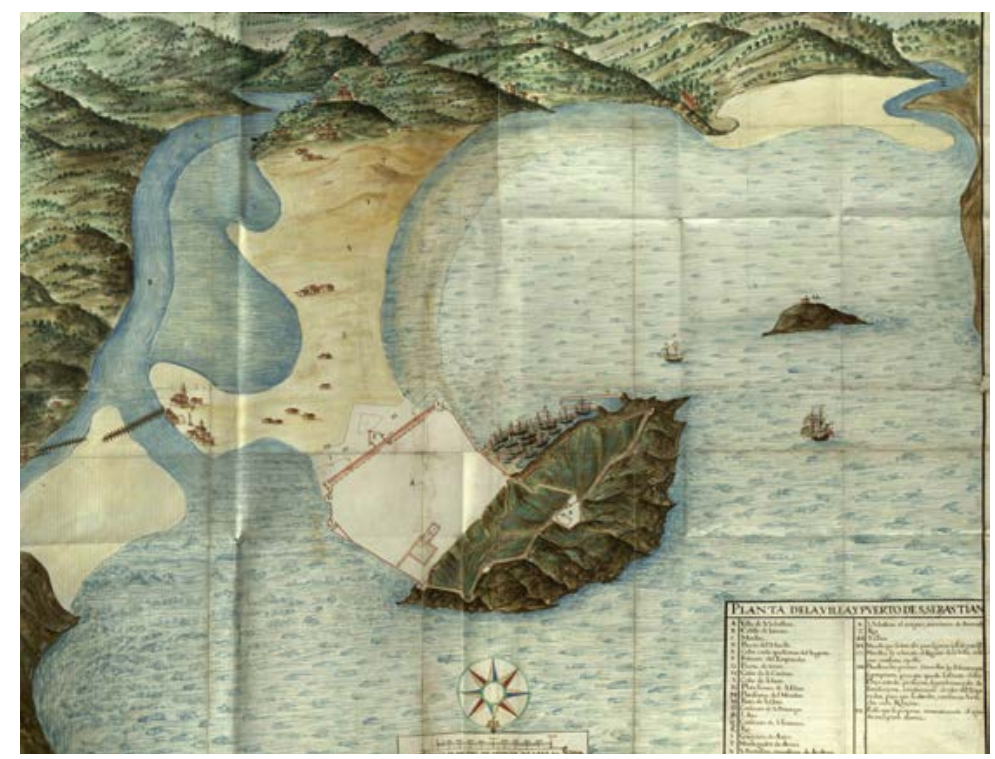

Figura 4. Proyecto de Soto, Texeira y Gandolfo para las fortificaciones de San Sebastián. 31 de marzo de 1636. Biblioteca Foral de Vizcaya. VMSS-249.

Además debía hacerse una muralla que conectara las defensas de la ciudad con el castillo de la Mota, ascendiendo con fuerte pendiente por las laderas, por el este y el oeste. Incluía una serie de baterías en puntos estratégicos desde los que se defendiera el puerto y la ciudad, y los accesos del enemigo por mar. También previeron fortificar Rentería, con una significativa ciudadela, el fuerte de Santa Isabel en Pasajes, el castillo de Higuer en Fuenterrabía ${ }^{40}$, etc. Y por lo que respecta a San Sebastián, un reducto en la isla de Santa Clara, el fuerte de San Bartolomé hacia el interior en la parte del convento del mismo nombre, y el fuerte

39. Parecer del Consejo sobre el informe de Marco Antonio Gandolfo. 1638. AGMM. Colec. Aparici, t. XI, 1-5-11, pp. 383-383v.; Gómez Piñeiro, F. J. y Sáez García, J. A.: Documentos cartográficos Históricos de Gipuzkoa en el Servicio Histórico Militar. Donostia-San Sebastián, 1999, p. 138.

40. Para mayor conocimiento del sistema defensivo de la frontera litoral en el Cantábrico, cfr. Truchuelo García, S.: «Fronteras marítimas de la Monarquía de los Habsburgo: el control de la costa cantábrica», Manuscrits. Revista de Hitòria Moderna, 32, 2014, pp. 36-41. 
de Santa Catalina delante del puente que cruzaba el Urumea ${ }^{41}$. Muchas de estas obras comenzaron a construirse, pero algunas se quedaron en proyecto o en fase de cimentación. Todas ellas fueron resultado del proyecto posterior de Marco Antonio Gandolfo ${ }^{42}$, cuya principal aportación al cabo del tiempo fue el gran hornabeque, que reforzaba la defensa y evitaba el problema de la excesiva altura del frente de Carlos V. Se construyó este a gran velocidad, por lo que pronto se encontró en estado de defensa ${ }^{43}$.

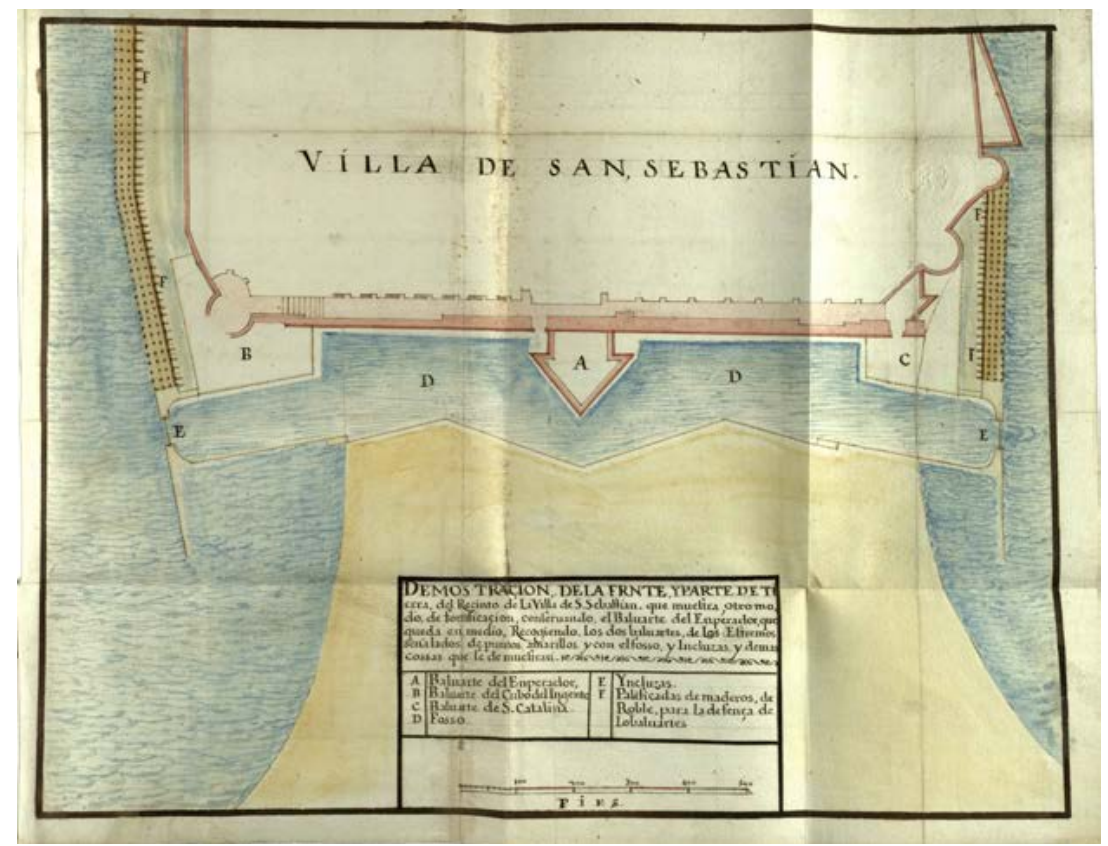

FiguRa 5. Descripción del frente real de las fortificaciones de San Sebastián. Gerónimo de Soto, Pedro Texeira y Marco Antonio Gandolfo. 31 de marzo de 1636. Biblioteca Foral de Vizcaya. VMSS-249.

41. Porras Gil, C.: La Organización Defensiva Española..., op. cit., pp. 187-189.

42. «El ornabeque o tenaza delante de la muralla de la plaza que mira al arenal esta levantado a toda la altura que ha de tener que es la de quince a diez y seis pies desde la banqueta de fuera, con el parapeto todo alrededor...». Carta de D. Gerónimo de Soto. 8 de octubre de 1639. AGMM. Colec. Aparici, t. XI, 1-5-11, pp. 490-507.

43. «Las fortificaciones de San Sebastián se hallan hoy todas comenzadas y casi en defensa, empeño que aunque no tuviera el credito de havellas diseñado Don Antonio Gandolfo, obligaba a proseguillas...». Carta de D. Luis Ponce de León sobre las fortificaciones de Guipúzcoa. 15 de octubre de 1639. AGMM. Colec. Aparici, t. XI, 1-5-11, pp. 3-10. 
Poco después se unió al trabajo de Gandolfo la figura del ingeniero Juan de Garay, que jugaría un importante papel en las fortificaciones de Pamplona ${ }^{44}$. Se pidió su parecer el 25 de mayo de 1640. Reafirmaba éste la necesidad de construir los fuertes destacados de San Bartolomé y Santa Catalina, además de realizar los brazos de conexión con el castillo. Y a final de ese año y durante 1641, Garay propuso otra obra de fortificación relevante. La presentaría el coronel Diego de Isasi. Se trataba de una ciudadela entre el castillo y la ciudad, en las faldas del monte Urgull. El 24 de diciembre se pidió opinión a Gandolfo, que vería con buenos ojos la propuesta. Finalmente Garay redactó un importante proyecto general, que incluía todas sus anteriores propuestas incluida la ciudadela, con tres amplios bastiones a media ladera (Fig. 6), aunque finalmente tal proyecto se desestimó ${ }^{45}$. Este ingeniero fue el impulsor de la construcción de los dos baluartes que debían reforzar los de Santiago y San Felipe, aunque una vez más estas obras se retrasarían tras el final del conflicto bélico.

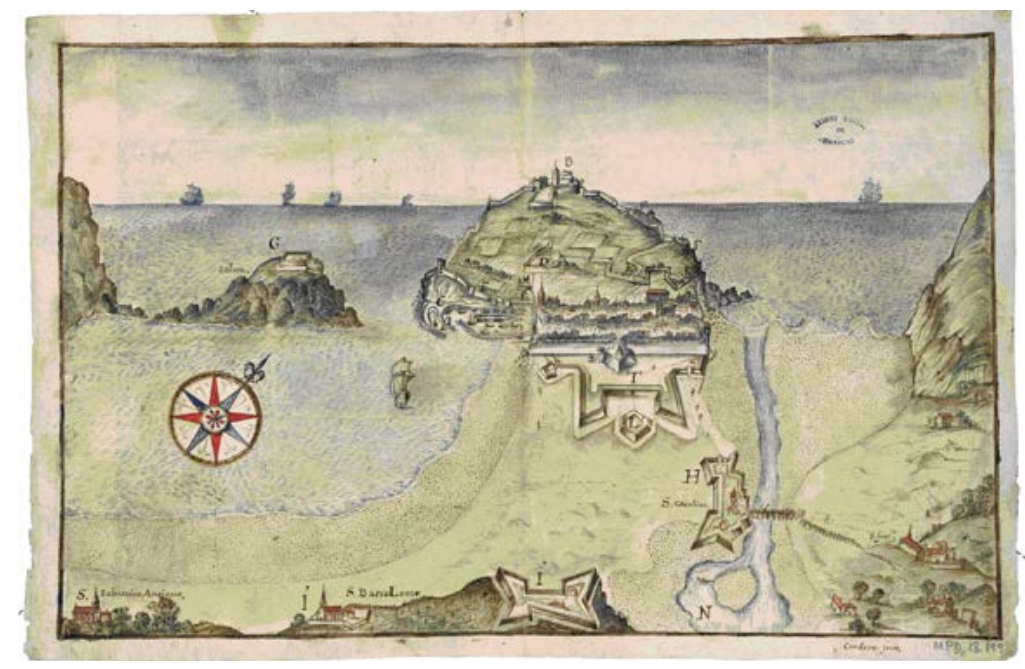

Figura 6. Proyecto de Juan de Garay para las fortificaciones de San Sebastián. Año de 1640. MECD. AGS. M.P. y D. XVIII-199.

44. Echarri Iribarren, V.: Las Murallas y la Ciudadela de Pamplona. Pamplona, 2000, pp. $240-244$.

45. Copia de Relacion y tanteo de lo que se juzga podra costar la fortificacion del fuerte o Ciudadela (...) en la montaña de la Mota sobre la Villa de San Sebastián en conformidad de la Planta que para ello a mostrado el señor Don Diego de Isasi Sarmiento... 6 de febrero de 1641. AGMM. Colec. Aparici, t. XI, 1-5-11, pp. 67-72. 
En la segunda mitad del siglo xviI, al igual que durante la Guerra de Sucesión ${ }^{46}$, se prosiguieron los trabajos del hornabeque hasta su finalización, y se redactaron algunos proyectos a cargo de ingenieros como Francisco Domingo y Cueva, Octaviano Meni o Hércules Torelli ${ }^{47}$, pero que no tendrían aplicación. En 1693 se terminó una de las obras más necesarias, la batería del Mirador ${ }^{48}$, en la ladera este del Urgull, que cubría las aproximaciones del enemigo desde el mar y desde la Zurriola. Tampoco durante la Guerra de Sucesión se produjeron modificaciones en las murallas. Durante la Guerra de la Cuádruple Alianza (1717-1720), San Sebastián y Fuenterrabía ${ }^{49}$ fueron sitiadas por el ejército francés del duque de Berwick en mayo y julio de 1719 respectivamente. San Sebastián fue atacada mediante baterías y trincheras desde la Zurriola, San Bartolomé y Santa Catalina ${ }^{50}$. Como era habitual, contaban con suficiente información de las características

46. Durante la Guerra de Sucesión algunos ingenieros franceses elaboraron ambiciosos proyectos para algunas plazas españolas, en los que aplicaban algunos de los principios establecidos por Vauban, y que circulaban por Europa como el nuevo paradigma de modernización de la fortificación abaluartada. Cfr. Vauban, S. le P.: Veritable Manière de Fortifier de Mr. de Vauban. Où l'on voit de quelle méthode on se sert aujourd'bui en France... París, 1689; Vauban, S. le P.: Traité des Siéges sur L'attaque et La Defense des Places de Guerre Par Monsieur De Vauban... La Haya, 1737; Chafrión, I.: Escuela de Palas o sea Curso Mathematico dividido en XI tratados, que contienen la Arithmetica, Geometria Speculativa... y ultimamente el Arte Militar. Milán, 1693.

47. Porras Gil, C.: La Organización Defensiva Española..., op. cit., pp. 198-200.

48. Sáez García, J. A.: «La galería de tiro del monte Urgull (San Sebastián)», Boletín de Estudios Históricos sobre San Sebastián, 37, 2003, pp. 353-398.

49. En Fuenterrabía atacaron desde el oeste. Abrieron con facilidad tres brechas desde las colinas del Cerezo y Santa Engracia, una en la cara izquierda del revellín de San Nicolás, otra en la cara derecha del baluarte de la Reina, y otra en la cortina entre este baluarte y el de San Nicolás. El 16 de junio se firmaban las capitulaciones, y la plaza caía en manos francesas, al mando del duque de Berwick. Las tropas hispanas reaccionarían meses después sitiando la vieja ciudad. En diciembre de 1719 las tropas francesas abandonaban Fuenterrabía, no sin antes haber volado por orden de Berwick, tras haberlos minado, los dos revellines exteriores del oeste.

50. «Francia envió al duque de Berwick al mando de 26.000 hombres, que cruzaron la frontera por Vera en 1719. Habían recibido la consigna de causar el menor daño posible. Tras la caída de Irún, Fuenterrabía y Hernani, el 1 de julio Berwick se instalaba en Ayete y comenzaba el sitio a San Sebastián. La ciudad capituló un mes más tarde». (ArTola, M.: Historia de Donosita-San Sebastián. San Sebastián, 2004, pp. 66-67). El 4 de julio comenzó el asalto y, poco a poco, los franceses fueron controlando los alrededores hasta que el día 25 ya estaban las baterías de cañones dispuestas para superar la muralla de la Zurriola. La noche del 26 al 27 Santa Catalina estaba en manos de los franceses y fortificaban la zona de Amara. El día 27 fue de «guerra total» con disparos de cañones por ambas partes, abriéndose dos importantes brechas en la muralla. Cfr. Tellechea Idígoras, J. I.: El asedio de San Sebastián (1719) por el Duque de Berwick: una guerra dentro de otra guerra. Donostia-San Sebastián, 2002, pp. 135-182. 
de las fortificaciones gracias a la labor de espionaje ${ }^{51}$. La ciudad capituló el 1 de agosto. Martín de Olózaga y Pablo Agustín de Aguirre, representantes de la ciudad, pactaron con Berwick la capitulación. La ciudad estuvo ocupada por una guarnición de 2.000 soldados franceses hasta el 25 de agosto de 1721 en que, por el Tratado de la Haya, fue evacuada. El ataque dejó dos brechas importantes: la primera en el lienzo de muralla antiguo entre los cubos de Amézqueta y de los Hornos, y la segunda entre este último cubo y el baluarte del Gobernador, en la parte izquierda del frente real (Fig. 8). Se generaba en esta parte un ángulo muerto perjudicial para la defensa. El ataque francés se había producido desde la Zurriola al otro lado del Urumea (Fig. 9). La batería o baluarte del Mirador era insuficiente para repeler el ataque, y había sufrido también daños importantes desde las baterías francesas.

\section{Primeros trabajos tras el ataque francés de 1719}

Durante la Guerra de Sucesión Felipe V introduciría una trascendente reforma en la formación y organización de los ingenieros militares. Para ello nombró en 1710 Ingeniero General a Jorge Próspero Verboom ${ }^{52}$, natural de Bruselas, que había gozado de una formación y experiencia única. Verboom organizó y modernizó el Cuerpo de Ingenieros Militares en sus primeros años en la Península, al tiempo que realizó en 1715 el proyectó de la ciudadela de Barcelona, emblema de la nueva era que se estaba tratando de iniciar. Importó a algunos ingenieros franceses y

51. Cfr. Orgeix, É. d': «Al servicio del rey. El espionaje francés de las plazas fuertes españolas en el siglo XVII», en CÁmara MuÑoz, A. (coord.): Los ingenieros militares de la Monarquía Hispánica en los siglos XVI y XVII. Madrid, 2005, pp. 97-111.

52. La biografía de Verboom, y especialmente su actividad en las diversas empresas bélicas de los Países Bajos a finales del siglo XVII y principios del XVIII, ha sido ampliamente tratada por Muñoz Corbalán en diversas publicaciones, una de ellas muy reciente. (MuÑoz Corbalán, J. M.: Los Ingenieros Militares de Flandes a España (1691-1718). 2 tomos, Madrid, 1993; MuÑoz Corbalán, J. M.: Jorge Próspero Verboom. Ingeniero militar flamenco de la monarquía hispánica. Madrid, 2015). En esta investigación se expondrán los aspectos y hechos relacionados con su actividad profesional de ingeniero, habiendo también consultado la documentación existente en el SHD y los Archives de l'Etat de Bruselas, entre otros. Consúltese también Wauwermans, H.: El Marqués de Verboom, ingeniero militar flamenco al servicio de España... Madrid, 1894; Hoja de servicios de Verboom, en AGMM. colec. Aparici, t. LIV, 6050; Llave y García, J. de la: «Don Jorge Próspero de Verboom. Marqués de Verboom», Memorial de Ingenieros, 28, 1911, pp. 109-160; Capel, H., Sánchez, J. E. y Moncada, O.: De Palas a Minerva. La formación científica y la estructura institucional de los ingenieros militares en el siglo XVIII. Madrid, Barcelona, 1988, pp. 14-56; CAPEL, H. et al.: Los ingenieros militares en España, siglo XVIII. Repertorio bibliográfico e inventario de su labor científica y espacial. Barcelona, 1983, pp. 472-479. 
VÍCTOR ECHARRI IRIBARREN

TERRITORIO Y SISTEMAS DEFENSIVOS DE FRONTERA: EL PROYECTO DE ISIDRO PRÓSPERO VERBOOM PARA LAS FOSTIFICACIONES DE SAN SEBASTIÁN EN 1726

flamencos que le habían ayudado en las campañas de los Países Bajos durante la reciente guerra ${ }^{53}$. Tras regresar Verboom de las campañas de Sicilia (1718-1720), emprendió la ingente tarea que visitar las plazas de la costa del Mediterráneo hasta Cádiz, realizando importantes proyectos de fortificación. Destacan los de Alicante ${ }^{54}$, Ceuta ${ }^{55}$, Málaga y Cádiz. Para esta labor fue acompañado de algunos expertos ingenieros, entre ellos su hijo Isidro Próspero, protagonista de esta investigación, que se encontraba en los primeros compases de una prometedora carrera profesional ${ }^{56}$. La elaboración de planos del territorio en todas estas plazas marcó un hito por la precisión y la descripción de todos los accidentes naturales, construcciones, obras públicas, etc. Tras una breve estancia en la Corte, emprendió en 1725 la tarea de redactar proyectos generales para las tres plazas de la frontera hispano-francesa occidental.

53. Cfr. Galland Seguela, M.: Les Ingénieurs Militaires Espagnols de 1710 à 1803. Madrid, 2008, pp. 37-52.

54. Echarri Iribarren, V.: «El proyecto general para las fortificaciones de Alicante en 1721», Hispania. Revista Española de Historia, 74:247, 2014, pp. 411-438.

55. Cfr. Ruiz Oliva, J. A.: Fortificaciones Militares de Centa: siglos XVI al XviII. Ceuta, 2002, pp. 205-234.

56. Isidro Próspero Verboom nació en Flandes en la década de los ochenta del siglo xvir. Estudió en la Academia Real y Militar del Ejército de los Países Bajos en Bruselas con Sebastián Fernández de Medrano, tiempo en que su padre Jorge Próspero era Cuartel Maestre e Ingeniero Mayor. Las primeras noticias de la labor de Isidro Próspero Verboom en España las tenemos durante el sitio de Barcelona en la Guerra de Sucesión. Posteriormente ayudó a su padre en los trabajos de dirección de obras de la ciudadela de Barcelona. Acompañó a su padre en 1718 en las campañas de Sicilia, en el sitio de Messina y la batalla de Francavila, entre otras. A su regreso dirigió los ataques de recuperación de Castelciudad. (cfr. AGS. GM. Leg. 3799). En 1719 es nombrado Ingeniero Director y Coronel. En mayo de 1721 acompaña a su padre Jorge Próspero en el viaje de reconocimiento de la costa del Mediterráneo español. Como Ingeniero en Jefe realiza un mapa de los ríos Castril y Guardal hasta Lorca. Realiza mapas de la jurisdicción de Granada y Murcia. Al año siguiente trabaja en Ceuta, donde realiza algunos planos del frente de las fortificaciones y de un aljibe. Posteriormente lo encontramos en Málaga en tareas relacionadas con las obras de ingeniería del puerto, junto con su padre. Desde julio de 1725 hasta finales de 1726 trabaja en San Sebastián en la redacción del proyecto que nos ocupa. Es destinado entonces como Ingeniero en Jefe a Santander realizando un mapa de la ciudad y sus contornos. En 1730 le encontramos trabajando junto con el ingeniero Juan de Subreville en la Línea del Campo de Gibraltar. Poco después su padre le propone a Felipe V para ser su sucesor en el cargo de Cuartel Maestre e Ingeniero General. Después de algunos trabajos en la Corte y en Sevilla, es nombrado en 1733 Brigadier y sustituto del Ingeniero General. Falleció ese mismo año viéndose truncada su prometedora carrera. Cfr. CAPEL, H. et al.: Los ingenieros militares en España, siglo XVIII. Repertorio bibliográfico e inventario de su labor científica y espacial. Barcelona, 1983, pp. 479-480. 


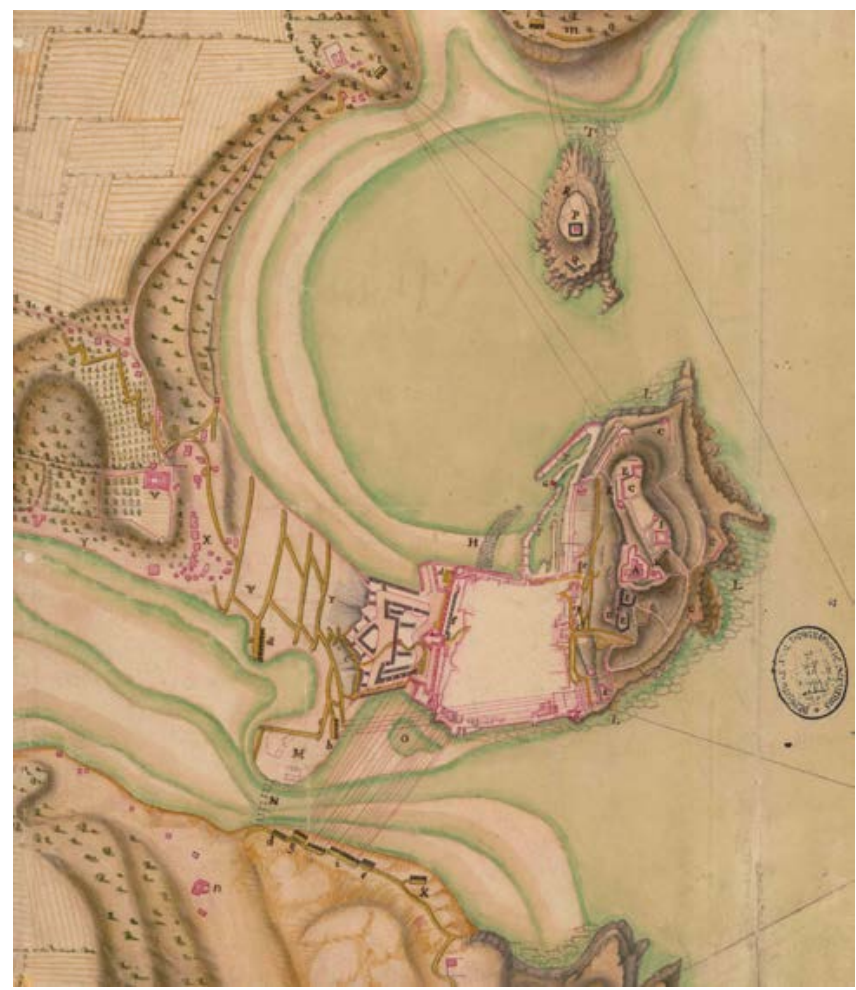

Figura 7. Ataque a San Sebastián por las tropas francesas de Berwick. Mayo-julio de 1719. Archivo General Militar de Madrid [en adelante AGMM]. SS 13-17.

Entre 1719 y 1725, años previos a la llegada de Isidro Próspero Verboom a San Sebastián, se sucedieron algunos trabajos, principalmente macizar las minas del ataque francés, armar con tierra y fajina compactadas los terraplenes desmoronados, y revestir de mampostería y sillares de piedra las dos brechas. Estos trabajos se finalizaron antes de la redacción del proyecto que nos ocup $\mathrm{a}^{57}$. Mientras que en Pamplona residían algunos ingenieros militares con más experiencia y estabilidad, como Ignacio Sala y Francisco Larrando de Mauleón, en San Sebastián y Fuenterrabía prevalecieron las estancias cortas, a veces motivadas por algunos desencuentros y rivalidades. Tras unos años sin Ingeniero Director en Guipúz-

57. Carta del Comandante General Luis de Fernández de Córdova al marqués de Castelar. 5 de noviembre de 1725. AGS. GM. Leg. 3432. 
VÍCTOR ECHARRI IRIBARREN

TERRITORIO Y SISTEMAS DEFENSIVOS DE FRONTERA: EL PROYECTO DE ISIDRO PRÓSPERO VERBOOM PARA LAS FOSTIFICACIONES DE SAN SEBASTIÁN EN 1726

coa, Verboom solicitó que se incorporara para tal tarea el prestigioso ingeniero francés Luis de Langot ${ }^{58}$. Llegó este en octubre de 1722, y residió principalmente en Fuenterrabía, que seguía teniendo prioridad estratégica frente a San Sebastián. También trabajaría Langot en Pamplona, realizando un importante proyecto, y en San Sebastián, aunque en esta dirigía las reparaciones de las brechas el Ingeniero Ordinario Antonio Álvarez Barba.

El primero objetivo era que Langot redactara proyectos para las tres plazas en cuestión, y así lo hizo el ingeniero francés. En Pamplona, al proyecto de Lagot se sumaron los de Ignacio Sala y Alejandro de Rez. Verboom redactaría uno propio en 1726, de mayor calidad e inteligencia que los anteriores ${ }^{59}$. En Fuenterrabía Langot redactó un interesante proyecto, alabado por Verboom, pero también corregido por el ingeniero de Bruselas ${ }^{60}$. En cambio, para San Sebastián, el proyecto general de Langot pasó desapercibido ${ }^{61}$, y Verboom dejó que su hijo Isidro hiciera un nuevo proyecto general en 1726, no realizando el Ingeniero General ninguna corrección ni proyecto alternativo. Además, dejó que firmara Isidro toda la colección planos anexos al proyecto -nada más y nada menos que treinta y siete-e incluyera en la cabecera de algunos de ellos la expresión «Proyecto General», algo que era exclusivo del Ingeniero General. Verboom estaba preparando a su hijo como su sucesor en el cargo, y quería que Isidro se luciera con un magnífico proyecto que avalara su capacidad. En 1731 Verboom redactaría un escrito de solicitud elevado al rey:

y que respecto de que el Brigadier e Ingeniero Director Dn. Isidro Prospero de Verboom, cuyos servicios quedan expuestos arriba, ha assitido al Supte. Desde que vino la España a todo lo que se ha ofrecido perteneciente a sus dos Empleos de Cuartel-Maestre General e Ingeniero General, de cuyas funciones se ha hecho capaz con la Practica, haviendo adquirido la necesaria para su desempeño; y que teniendo estos Empleos tanta relacion entre si, que combiene recaigan ambos en un Ingeniero, se digne V.M. conceder al referido Dn. Isidro Prospero la futura de Ellos, y entretanto la facultad de ejercerlos en las ausencias y enfermedades del Supte ${ }^{62}$.

58. Carta de Verboom dirigida al marqués de Castelar. Informe sobre las fortificaciones de San Sebastián. 28 de febrero de 1722. AGS. GM. Leg. 3432.

59. Echarri Iribarren, V.: Las Murallas y la Ciudadela de Pamplona. Pamplona, 2000, pp. $418-430$.

60. Echarri Iribarren, V.: «El Proyecto de Jorge Próspero Verboom para las Fortificaciones de Fuenterrabía», Tiempos Modernos. Revista Electrónica de Historia Moderna, 8:34, 2017, pp. 202-233.

61. «...en el interin que se toma resolucion sobre el proyecto general del Ingeniero Dn. Luis de Langot». Carta del marqués de Mirabel. 23 de octubre de 1724. AGS. GM. Leg. 3432.

62. Escrito de petición de nombramiento de Isidro Próspero Verboom como Ingeniero General. Jorge Próspero Verboom. 1731. AGS. GM. Leg. 3799. 
Además es preciso indicar que, de todos los proyectos de ingeniería militar realizados en España, el de San Sebastián que nos ocupa supera a todos en calidad gráfica y extensión, sobresaliendo por encima de plazas tan emblemáticas como Barcelona, Pamplona, Badajoz o Cádiz. Sorprende este hecho además por tratarse de propuestas de poca envergadura: unos pocos refuerzos o ampliaciones de baluartes, alguna contraguardia, y baterías en el monte Urgull, como se verá más adelante.

Es probable que esta política nepotista de Verboom fuera la causante de algunas controversias sucedidas en estos años en las plazas de Navarra y Guipúzcoa. En 1721, tras apenas un año de estancia en Pamplona como Ingeniero Director, el prestigioso y experimentado ingeniero Carlos Robelin, fue trasladado a Zamora para ocuparse de las plazas de la frontera hispano-lusa. Su proyecto de subterráneos y bóvedas a prueba de bomba en la ciudadela de Pamplona no había sido seguido por los ingenieros Francisco Larrando de Mauleón y Alejandro de Rez, Ingeniero Director de las plazas de Cataluña, y se habían producido importantes desperfectos y humedades. Estos le habían acusado gravemente de negligencia, y Verboom había decidido mantenerlo como Ingeniero Director, pero en una demarcación de segunda fila comparada con la frontera hispano-francesa. A primera vista parecería un hecho de diferencias técnicas, pero las causas debieron ser otras si atendemos a los escritos que Robelin dirigió a la Corte en defensa propia y lanzando graves acusaciones contra Verboom. Solo una persona de su valía y trayectoria podía permitirse el lujo de tales formas. A esto hay que sumar las diferencias que surgieron en 1725 entre Langot y Verboom con motivo de la redacción de los proyectos generales para las plazas de Fuenterrabía y San Sebastián. Su hijo Isidro llegó incluso a visitar Fuenterrabía para aportar ayuda e información a su padre, algo que se salía de la práctica habitual, y que molestó sin duda a Langot. Verboom habría camino a su hijo y necesitaba elevarlo por encima de algunos Ingenieros Directores tan valiosos como Robelin y Langot. Poco después Verboom realizaría la petición formal al rey para que su hijo Isidro fuera quien que le sucediera como Ingeniero General ${ }^{63}$. El rey lo aprobó el 26 de junio de 1731 . Solo la muerte de Isidro en 1733 impidió que tal hecho se llevara a efecto.

\section{El proyecto de Isidro Próspero Verboom para San Sebastián}

Es momento de describir brevemente las principales propuestas y virtudes del proyecto de Isidro, aunque como hemos visto se trata de un conjunto de directrices para una plaza de segundo orden en la defensa peninsular, y las circunstancias

63. Escrito de petición de nombramiento de Isidro Próspero Verboom como Ingeniero General. Jorge Próspero Verboom. 1731. AGS. GM. Leg. 3799. 
que lo envuelven hacen que los aspectos técnicos sean menos relevantes que los personales y organizativos. Acompañaremos la exposición de las principales propuestas con unos pocos de los treinta y siete planos del proyecto, conservados en el Centro Geográfico del Ejército de Tierra [en adelante CEGET] ${ }^{64}$.

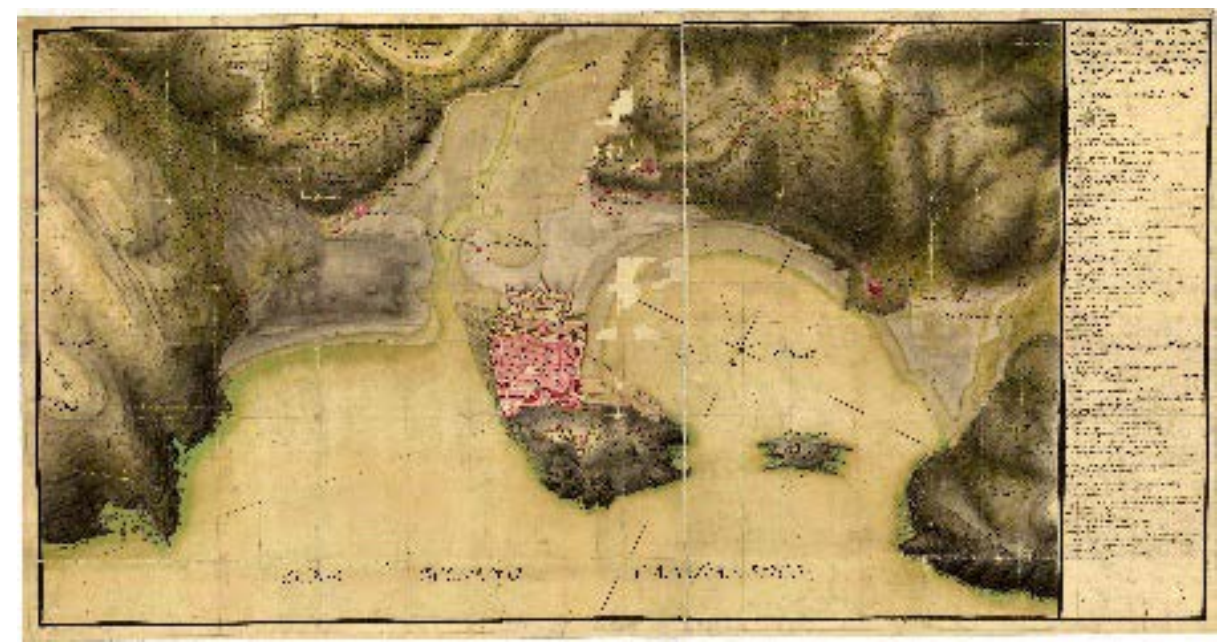

Figura 8. Plano de San Sebastián y sus contornos. Proyecto General de Isidro Próspero Verboom. 1725. CEGET. Ar. F-T.2-C.1-168.

En un plano de territorio describía los accidentes existentes alrededor de la plaza, ribazos, edificaciones, arenales, etc., que sirvieran para planificar una adecuada defensa en una milla -de este a oeste- o dos millas -de norte a sur-alrededor de las fortificaciones (Fig. 8). Fue el plano topográficamente más preciso de la plaza y sus alrededores delineado hasta el momento, dentro de la serie de planos que el equipo de Verboom acometió desde 1721. Fue delineado en 1725. No sabemos con precisión cuándo llegó Isidro Próspero de Verboom a San Sebastián. En alguna documentación de abril y mayo de 1725, en que se instaba a proseguir con las obras de las brechas, se hace mención a Langot o Álvarez Barba, pero no se menciona a los Verboom. Es seguro que su llegada fue posterior. Por la correspondencia posterior de Verboom padre con Langot desde Pamplona,

64. A pesar de la amplia documentación cartográfica sobre San Sebastián conservada en el AGMM, no se conservan en este archivo planos de esta serie de Isidro Próspero Verboom. Cfr. Gómez Piñeiro, F. J. y Sáez García, J. A.: Documentos cartográficos Históricos de Gipuzkoa en el Servicio Histórico Militar. Donostia-San Sebastián, 1999. 
de finales de septiembre, sabemos que fue entre estos meses. Algunos planos de Isidro llevan fecha de julio. Es del todo probable que fuera a principios del mes de julio cuando padre e hijo llegaran juntos a Pamplona, y posteriormente Isidro se desplazara a San Sebastián. Dicha hipótesis encajaría bien con la documentación y la labor que Jorge Próspero desarrolló en la capital de Navarra.

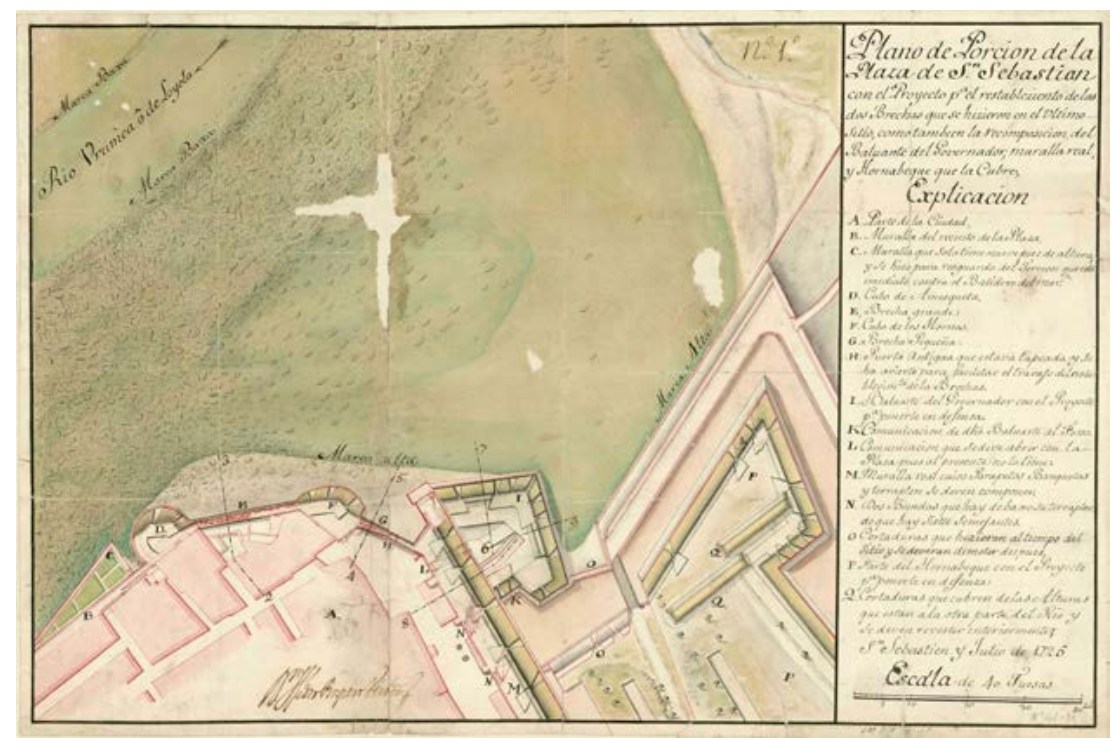

FiguRA 9. Proyecto del restablecimiento de las brechas del sitio de 1719. Isidro Próspero Verboom. Julio de 1725. CEGET. Ar.F-T.2-C.1-170(a).

Las fechas de los treinta y siete planos discurren entre julio de 1725 y junio de 1726. En cambio las dos memorias más significativas que reflejan su proyecto, llevan fechas de 26 de enero de 1726, y 16 de junio de 1726. La primera es una exposición del estado y tanteo del coste de las obras de las fortificaciones de la ciudad y castillo de la Mota ${ }^{65}$, mientras que la segunda es una relación de las obras necesarias para la plaza, con comentarios referentes a las carencias defensivas o defectos de las fortificaciones ${ }^{66}$. Todo parece indicar que hubo otras memorias previas, ya que el tanteo debería ser

65. Relación de las obras que faltan a esta plaza y castillo de la Mota para ponerlo en estado de defensa. Isidro Próspero Verboom. 16 de junio de 1726. AGS. GM. Leg. 3432.

66. Estado y Tanteo Prudencial de lo que podran importar las obras de fortificaciones de la Plaza de San Sebastian, su Castillo... Isidro Próspero de Verboom. 26 de enero de 1726. AGS. GM. Leg. 3432. 
posterior. Lo más lógico es que Isidro hubiera hecho un primer proyecto entre julio y septiembre de 1725 , cuya memoria no se conserva, y que acompañaría a los planos de esa fecha (Figs. 11, 14 y 19). Posteriormente debió elaborar otra corregida en enero de 1726, que es la que va junto con el tanteo de las obras. Esto encajaría con que Verboom padre hacía lo propio en esa fecha para el complejo proyecto de las fortificaciones de Pamplona. Y finalmente en junio de 1726 hizo una tercera memoria de proyecto. Es de suponer que las tres no serían coincidentes al cien por cien, pero solo podemos describir la única que se ha conservado. Como decimos, en ella Isidro Próspero de Verboom va indicando las deficiencias existentes en los diversos elementos. Coincidía con la valoración general del marqués de Mirabel:

no puedo menos de informar a VS la precision de la composición de todas ellas por hallarse indefensas y entteramente abiertas, y que de dejarse se seguira maior perjuicio a SM pues las continuadas llubias y ynclemencias del tiempo las reducirá a maior costo en su tardanza $\mathrm{Y}$ hallandonos aora en la estacion de la primabera y ymportando tantto a SM el que se ejecuten estas obras con la maior vrevedad es inescusable a mi obligación dejar de prevenirselo a VS para que poniendolo en noticia del Rey se sirva dar las ordenes mas combenientes para su ejecuzion ${ }^{67}$.

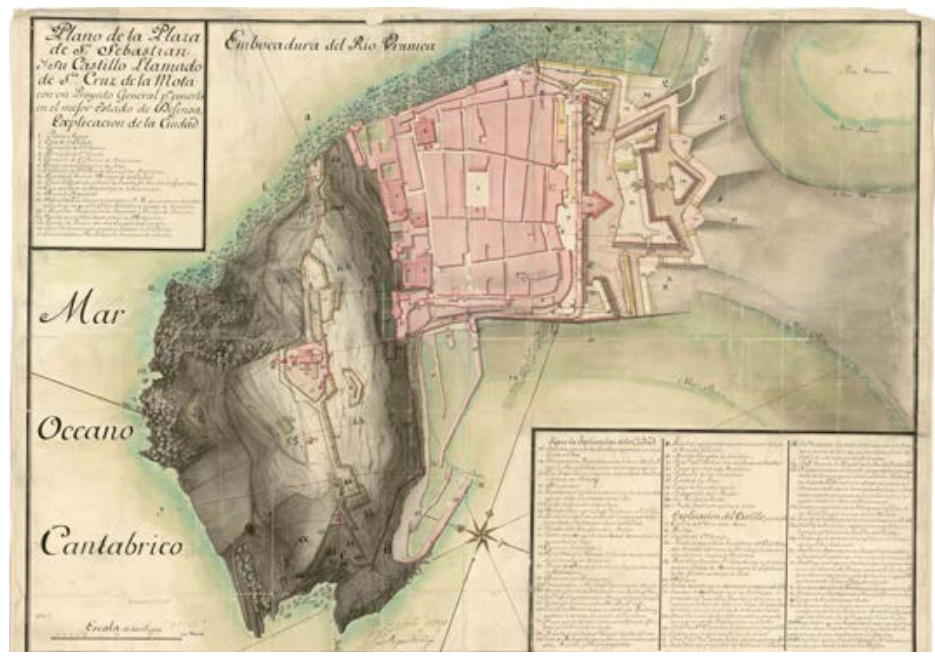

Figura 10. Plano de la Plaza de San Sebastián y su Castillo llamado Sta. Cruz de la Mota, con un Proyecto General.... Isidro Próspero Verboom. Junio de 1726. CEGET. Ar.F-T.2-C.1-178.

67. Carta del marques de Mirabel al marqués de Castelar. 16 de abril de 1725. AGS. GM. Leg. 3432 . 
A continuación se expondrán por orden de importancia las propuestas más significativas de Isidro Próspero de Verboom, extraídas de la memoria de 16 de junio de 1726 y que se exponían en un detallado plano (Fig. 10). Se ampliarán, cuando sea preciso, con algún comentario contenido en el estado y tanteo de costes de las obras de fecha 26 de enero de 1726:

1. Proyecto de refuerzo del baluarte del Gobernador, en la parte izquierda del frente real. Había sido el punto por el que el enemigo había abierto las dos brechas en el último sitio. Isidro describía primero el estado en que se encontraba (Fig. 9), para posteriormente plantear un atractivo proyecto escalonado en tres alturas hacia el este (Figs. 11 y 12). Primero suprimía la presencia de los cubos de Amézqueta y de los Hornos -tan problemáticos- con una nueva cortina que iba desde el primer cubo hasta el baluartillo de san Telmo. Esta formaba un pequeño flanco, para recoger una cortina que enlazaba con una batería dispuesta delante del cubo de los Hornos. Quedaba este conjunto a la altura del primer recinto original de la plaza. El acceso del enemigo era dificultado por el mar y el arenal que se producía en bajamar. En su proximidad con el baluarte del Gobernador, esta dificultad natural desaparecía. Aquí Isidro disponía una segunda línea a menor altura, a modo de falsabraga ${ }^{68}$. Y debajo del baluarte del Gobernador, hacía otro baluarte bajo muy capaz, con nueve troneras. De esta forma conseguía un escalonamiento en tres niveles hacia el mar por la parte este del frente real (Fig. 5), reforzando mucho la defensa con un coste bajo de las obras. La única dificultad objetiva eran los trabajos de cimentación en un terreno que debía pilotarse. Para poder llevar a cabo toda esta obra había de demolerse una cortadura con tres troneras que se había hecho en el sitio de 1719. Este diseño de Isidro estaba en consonancia con el proyecto que en las mismas fechas hacía su padre para Pamplona. En el frente de Francia, cuyos lienzos eran muy elevados sobre el nivel del río, disponía baluartes bajos y un revellín ${ }^{69}$. Treinta años después, el sucesor de Verboom como Ingeniero General, Juan Martín Zermeño, redactaría un proyecto en que añadía flancos bajos a los baluartes del Labrit y Guadalupe ${ }^{70}$, teniendo mayores similitudes todavía con esta propuesta de Isidro.

68. Estado y Tanteo Prudencial..., op. cit. AGS. GM. Leg. 3432, p. 2.

69. Cfr. Echarri Iribarren, V.: Las Murallas y la Ciudadela de Pamplona. Pamplona, 2000, p. 423. CEGET. Ar.F-T.3-C.2-407(1); Ar.F-T.3-C.2-407(4).

70. Cfr. Echarri Iribarren, V.: «El proyecto de Juan Martín Zermeño para las fortificaciones de Pamplona: una revisión del Proyecto General de Verboom», Tiempos Modernos. Revista Electrónica de Historia Moderna, 8:30, 2015, pp. 426-457. 


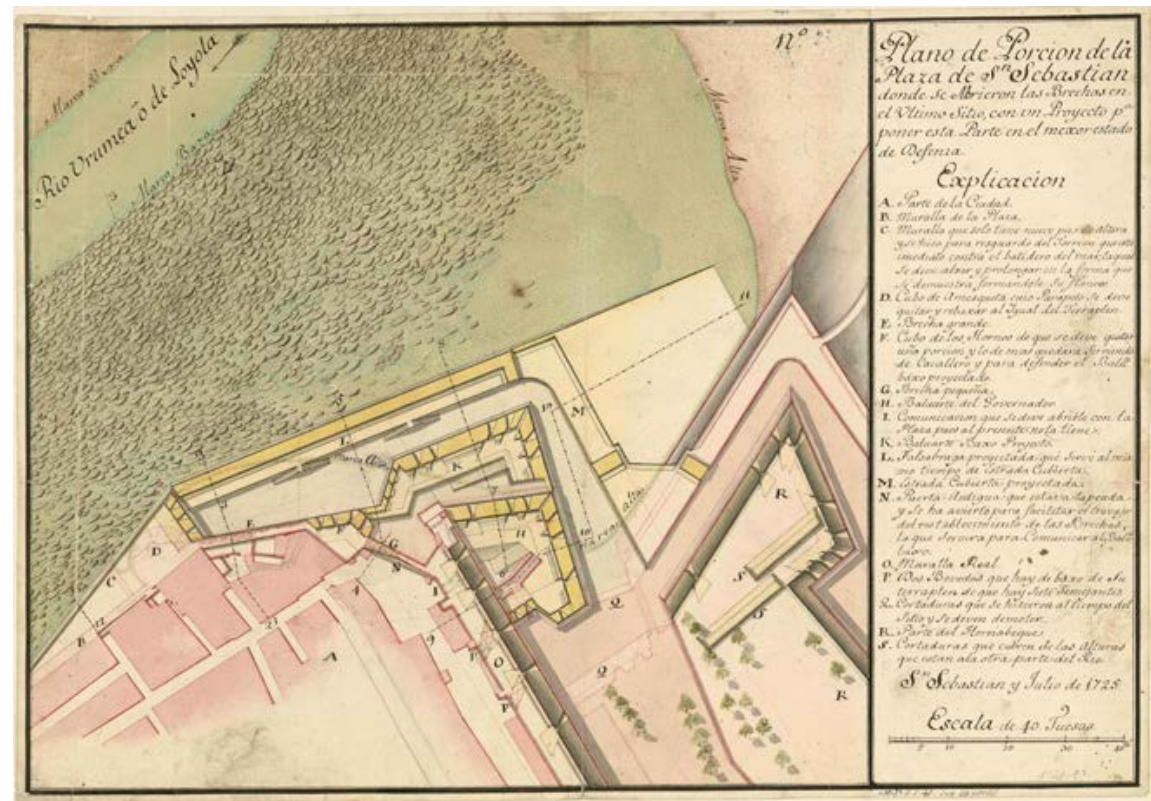

Figura 11. Propuesta de Isidro Próspero Verboom para reforzar el baluarte del Gobernador. Julio de 1725. CEGET. Ar.F-T.2-C.1-171 bis(a).

2. Nueva contraguardia delante del baluarte nuevo o de San Felipe, en la parte derecha del frente real. Se había erigido tiempo atrás un guardamar que hacía como de contraguardia, pero "por su mala situacion y construccion y poco espesor de sus murallas», era más un estorbo. Dado que Isidro proponía construir una nueva contraguardia, y que esta sería una obra de entidad que reforzaría las defensas en un punto de grave importancia, proponía mejorar el guardamar con «parapetos y banquetas con fajinas», hasta que la contraguardia estuviera operativa ${ }^{71}$. De esta forma podrá servir para una mediana defensa. La contraguardia era la segunda pieza de proyecto en importancia. Posteriormente se seguirían redactando proyectos de detalle para su ejecución, siguiendo como proyecto director el elaborado por Isidro. El hornabeque de Gandolfo no cubría de forma satisfactoria la cortina del frente real en su parte derecha. Esta era además demasiado elevada, y se precisaba escalonar la defensa en altura, algo similar a lo efectuado en el baluarte del Gobernador. La construcción también era compleja por las dificultades en cimentarla.

71. Relación de las obras que faltan a esta plaza y castillo..., op. cit., pp. 2-3. 


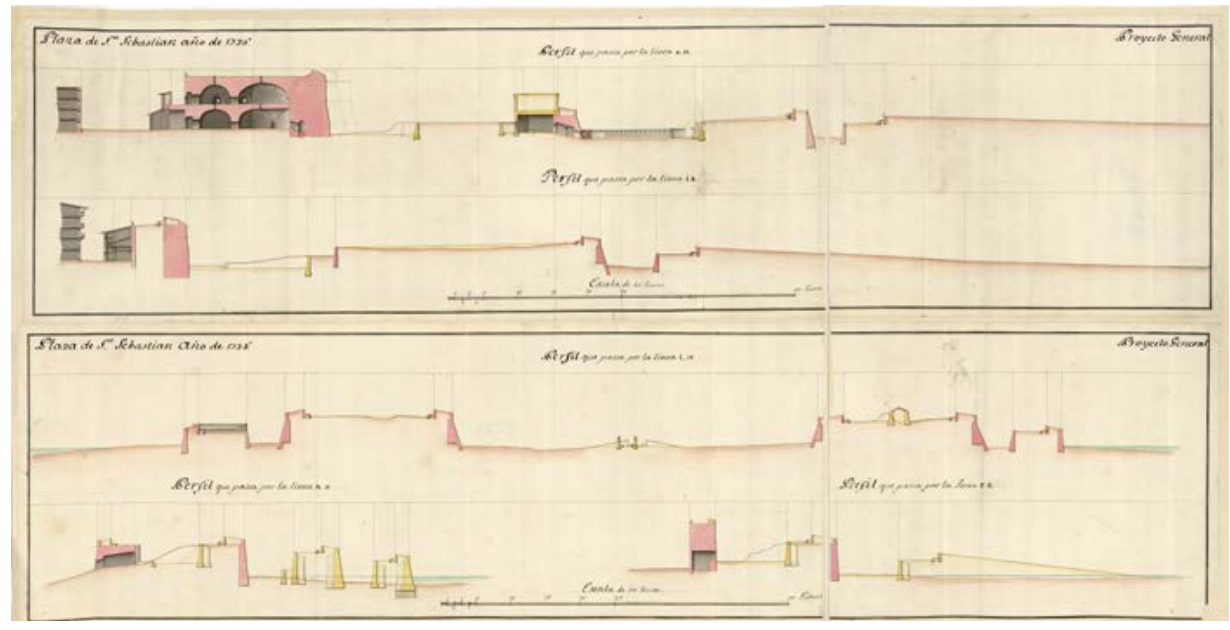

Figura 12. Perfiles del frente real. Cubo Imperial y proyecto del baluarte del Gobernador. Isidro Próspero Verboom. Junio de 1726. CEGET. Ar.F-T.2-C.1-178 bis(b).

3. Reformas en el baluarte de San Felipe. Previamente al sitio de 1719 se había formado todo el terraplén, y levantado por la parte interior un estribo de mampostería en su ángulo flanqueado. De esa forma se impedía que los muros que formaban el ángulo flanqueado del baluarte, que estaba agrietado y con peligro de caída, se vieran aliviados del empuje de las tierras ${ }^{72}$. Exponía con detalle las reformas necesarias:

se devera levantar de algunos pies la Cara derecha del dho Baluarte [nuevo o de San felipe], hacer tres Bovedas a prueva de Bomba, en el flanco Izquierdo, dejando en una de ellas una Puerta para salir al foso, y perfeccionar el terraplen, dejando por ahora de levantar la muralla del revestimiento interior de los parapetos y vanquetas por los mismos motivos que se expresan tocante a los del Baluarte del Governador y hacerlos tambien de faxina en caso de precision. Y se deveria asimismo acavar la Puerta que se ha avierto devajo de la muralla Real en la Gola de este Baluarte que tambien carecia de tan precisa comunicación, como el del Governador ${ }^{73}$.

72. Relación de las obras que faltan a esta plaza y castillo..., op. cit., pp. 4-5.

73. Relación de las obras que faltan a esta plaza y castillo..., op. cit., p. 5. 


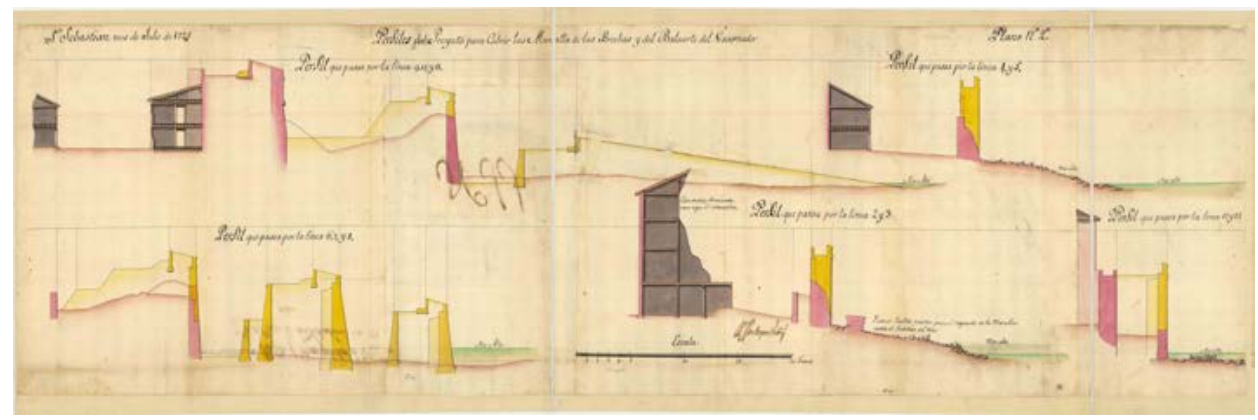

Figura 13. Perfiles. Isidro Próspero Verboom. Junio de 1726. CEGET. Ar.F-T.2-C.1-171 (b).

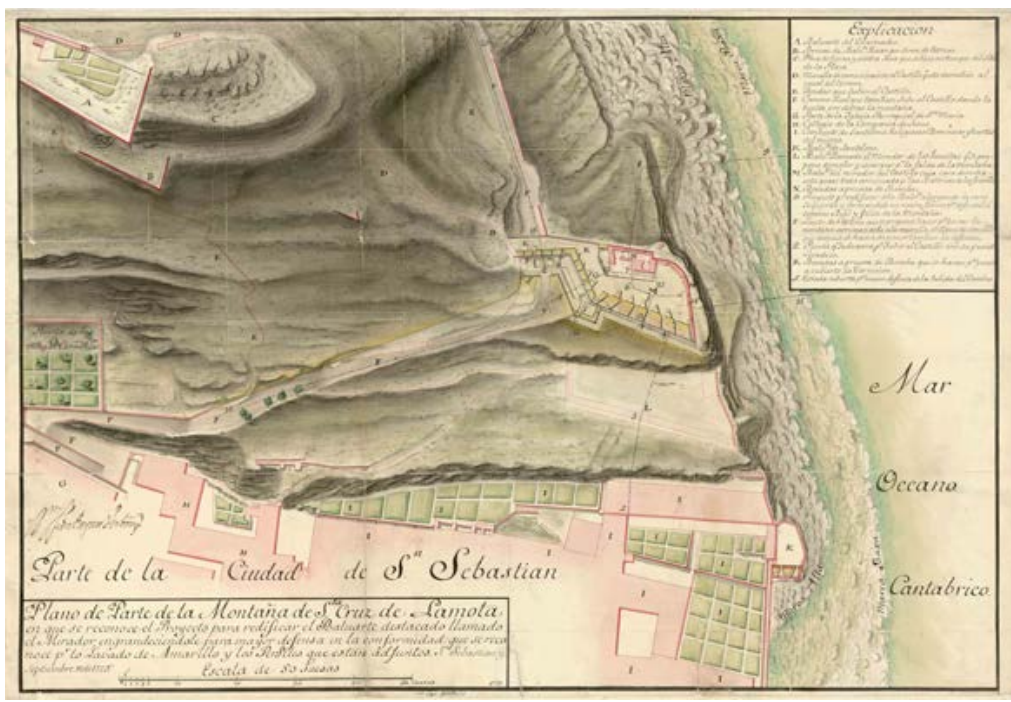

Figura 14. Proyecto para el Baluarte del Mirador. Isidro Próspero Verboom. 12 de septiembre de 1725. CEGET. Ar.F-T.2-C.1-173 (a).

4. Baluarte destacado del Mirador, en la ladera este del monte Urgull. Durante el sitio de 1719 había sido profundamente dañado. Miraba hacia las alturas de la zona de la Zurriola, donde los franceses establecieron seis baterías con numerosas piezas de artillería. Isidro había proyectado su recomposición al poco de llegar a San Sebastián, estableciendo algunas variaciones. Firmaba el plano de detalle 
el 12 de septiembre de 1725 (Fig. 14). Estaban muy avanzadas las obras en junio de 1726. El proyecto consistía en una reedificación y prolongación de la cara derecha -muy dañada por los franceses- y un flanco derecho con troneras, cuya misión era defender el camino real que ascendía al castillo de la Mota. Se cerraba este flanco con un lienzo que se arrimaba a la muralla antigua de comunicación. Se hacía una puerta con puente levadizo para proteger la subida al castillo. Esta intervención iba acompañada de la demolición del baluarte del Mirador de los Jesuitas, que era contrario a la defensa, escarpando las tierras y peñas de la falda de la montañ ${ }^{74}$. De esta forma se conseguía disponer una batería que no podía ser minada ni abrirla brecha desde el interior de la plaza, una garantía sin duda para la defensa del castillo, que podría resistir durante mucho tiempo y prolongar notablemente el sitio. Incluía este baluarte algunas bóvedas a prueba de bomba para poner a cubierto la guarnición.

5. El castillo de la Mota necesitaba atenciones. Se había reparado uno de los aljibes, que perdía agua. Enlozaba todas las explanadas de la plaza de armas para conducir el agua a los aljibes existentes. Proyectaba algunas bóvedas a prueba de bomba para almacén de víveres, hospital y abrigo para la guarnición. También un almacén capaz de contener dos mil quintales de pólvora para tiempo de sitio, y otro sencillo para tiempo de paz $^{75}$. Los disponía en las cortinas que miraban al norte y al oeste, logrando también engrandecer la plaza de armas (Fig. 15).

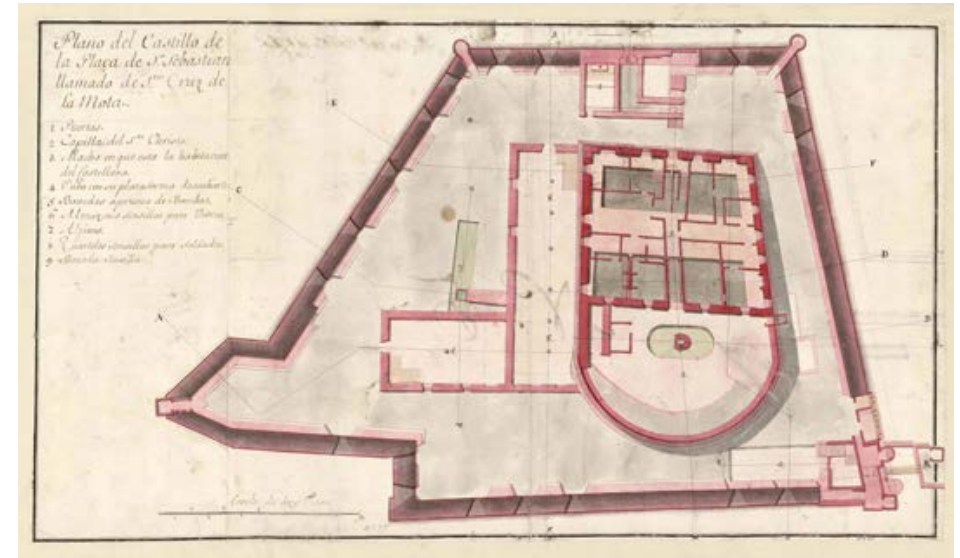

Figura 15. Plano de la Plaza de San Sebastián y su Castillo llamado Sta. Cruz de la Mota. Isidro Próspero Verboom. Junio de 1726. CEGET. Ar.F-T.2-C.1-178.

74. Relación de las obras que faltan a esta plaza y castillo..., op. cit., pp. 8-9

75. Relación de las obras que faltan a esta plaza y castillo..., op. cit., p. 10. 
6. Baluartes destacados en Urgull (Fig. 16). Eran piezas esenciales para batir las aproximaciones del enemigo por tierra y mar. Revestía de piedra los parapetos de todos ellos, especialmente de los del Gobernador y Santa Clara, a derecha a izquierda del castillo. Proyectaba uno nuevo con comunicación al castillo, debajo de este y con dos caras simétricas, que se había comenzado en $1725^{76}$.

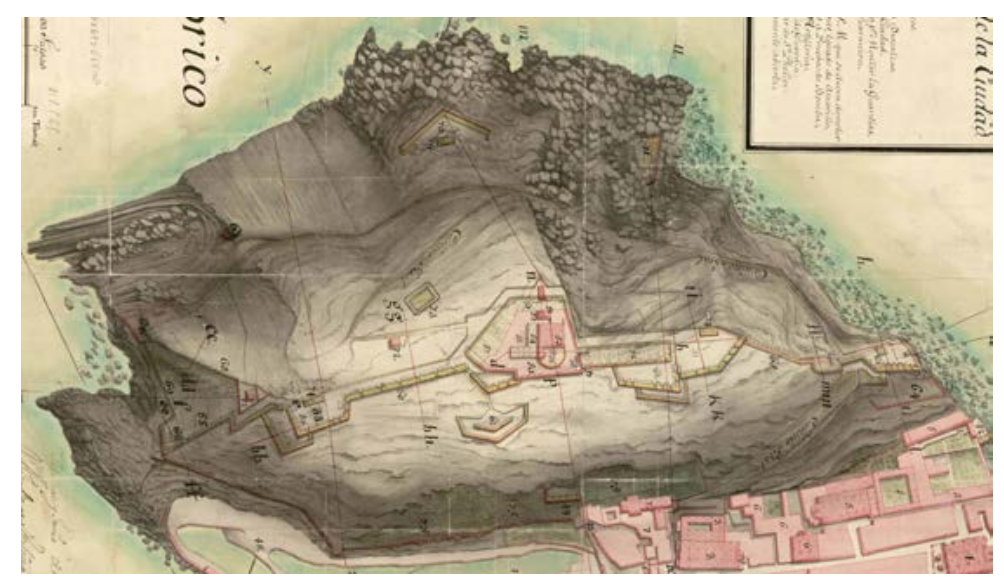

Figura 16. Detalle de la Fig. 10. Baterías en el monte Urgull. Isidro Próspero Verboom. Junio de 1726. CEGET. Ar.F-T.2-C.1-178.

También proyectaba al oeste una batería más baja que la de Santa Clara que flanqueaba la montaña por encima de los muelles, haciendo causa común con el baluarte de la Fuente, que defendía la entrada del puerto. Y al norte el baluarte de las Batuecas, con los parapetos resueltos a «barbeta» para impedir que arribaran las embarcaciones (Fig. 17). En la batería que se había comenzado hacía algunos años al noreste de la montaña, proponía la ubicación de un almacén a prueba de bomba, para ponerlo en tiempo de sitio. Tenía la ventaja de encontrarse completamente resguardado por grandes peñascos.

7. Proyectaba dos comunicaciones a derecha e izquierda del castillo (Fig. 16), esenciales para la defensa, pues a través de ellas se cerraba la montaña por la parte de tierra, «que es el unico ataque, porque por la del mar, no es dable que un enemigo pueda hacer desembarco por lo escarpado de las Peñas, contra las quales

76. Relación de las obras que faltan a esta plaza y castillo..., op. cit., p. 11. 
rompe el mar continuamente» ${ }^{77}$. Al este enlazaba con el baluarte del Mirador, y al oeste con el baluarte de la Fuente.

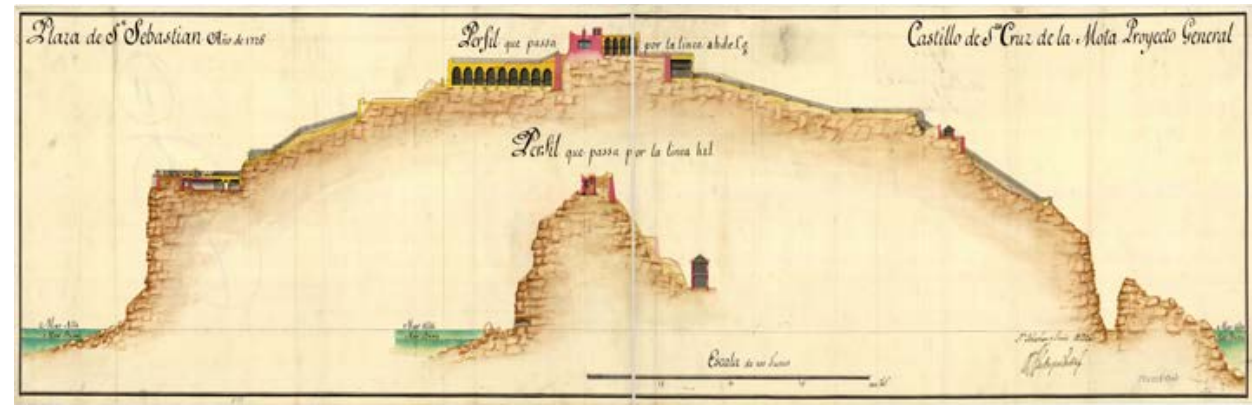

Figura 17. Perfiles de las baterías del monte Urgull. Isidro Próspero Verboom. Junio de 1726. CEGET. Ar.F-T.2-C.1-178 (g).

8. Hornabeque y revellín delante de la cortina real (Fig. 18). Estaban en estado de defensa, pero se precisaban algunas escaleras de comunicación con el foso, concluir las banquetas, etc. Lo más significativo es que se habían parado las obras de la bóveda a prueba de bomba situada en la mitad de la cortina, que serviría para abrigo de la guarnición, y que tampoco se había hecho la caponera de comunicación del revellín con la cortina del hornabeque.

9. Batería proyectada en la isla de Santa Clara. Isidro la había proyectado en mayo de 1726, pero un mes después, en la memoria que estamos analizando, no se decía nada al respecto. La isla era inaccesible por lo escarpado de las rocas en todo su perímetro. En el último sitio, alrededor de la ermita de Santa Clara, se habían hecho algunos atrincheramientos. Ahora Isidro proyectaba una batería con diez troneras que tendría una doble misión (Figs. 19 y 20). Por un lado enfilaría las trincheras que previsiblemente haría el enemigo delante de la plaza por la parte de San Bartolomé, como sucediera en el último sitio. Por otra parte defendería las aproximaciones del enemigo en la montaña, junto con el baluarte del Mirador. Así se describía en una memoria previa a la llegada de Isidro a San Sebastián ${ }^{78}$. Verboom hijo añadía también un almacén de pólvora a prueba de bomba, y proyectaba un embarcadero hacia el este.

77. Relación de las obras que faltan a esta plaza y castillo..., op. cit., p. 11.

78. Estado de los reparos que el Gobernador D. Juan Alabes pide se hagan prontamente en esta Plaza de San Sebastián. 27 de mayo de 1725. AGS. GM. Leg. 3432. 


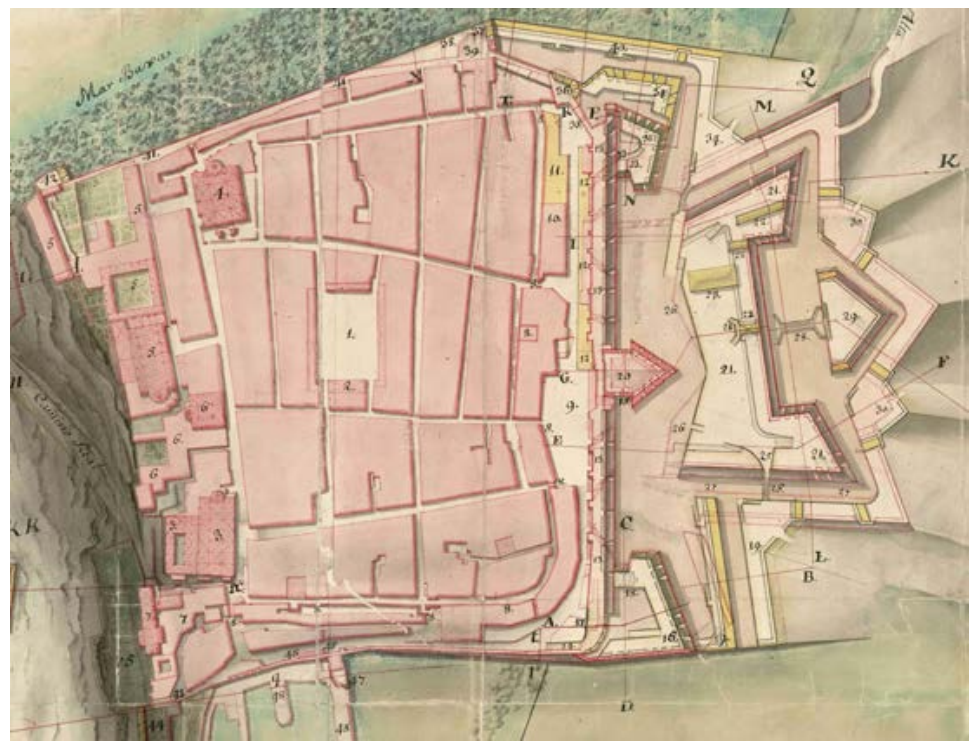

FIgURA 18. Frente real y hornabeque, con los proyectos del baluarte del Gobernador y la contraguardia delante del baluarte de San Felipe. Isidro Próspero Verboom. Junio de 1726. CEGET. Ar.F-T.2-C.1-178.

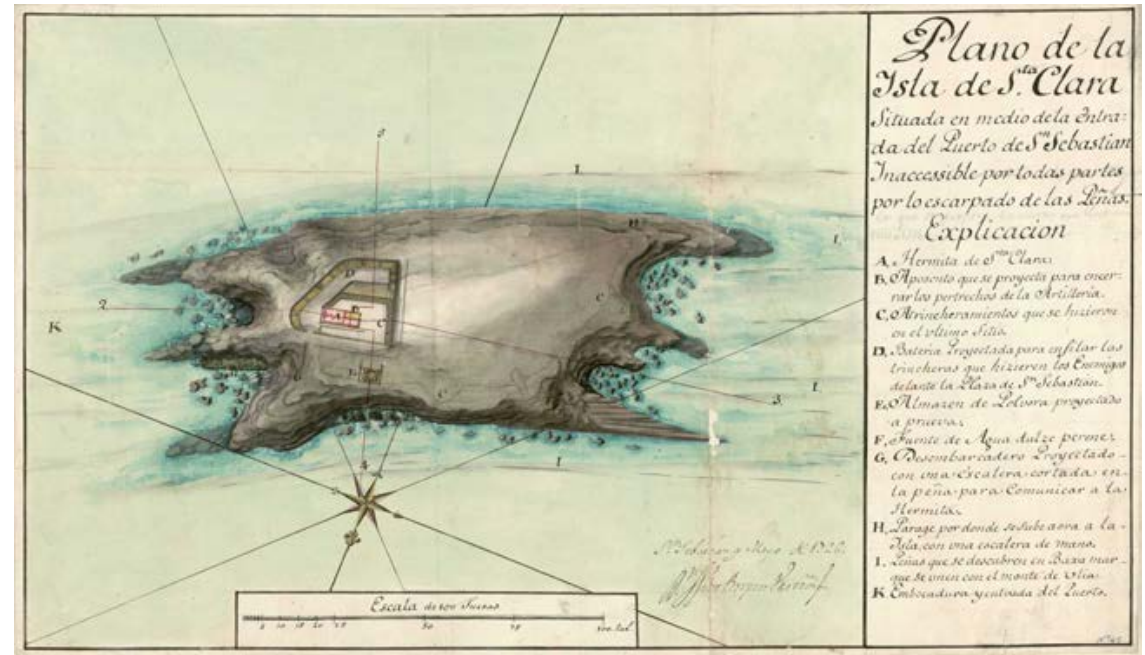

Figura 19. Batería proyectada en la isla de Santa Clara. Isidro Próspero Verboom. Mayo de 1726. CEGET. Ar.F-T.2-C.1-177(1a). 


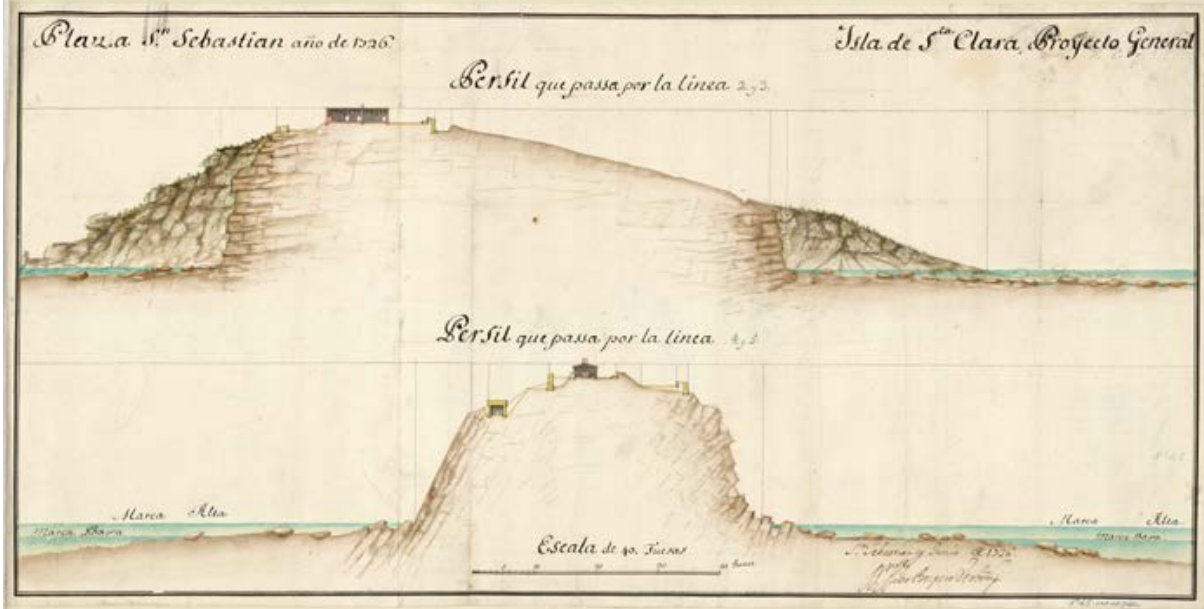

FIgura 20. Perfiles. Isidro Próspero Verboom. Junio de 1726. CEGET. Ar.F-T.2-C.1$177(1 \mathrm{~b})$.

Estas eran en resumen las obras más significativas del proyecto general Isidro Próspero Verboom, que se muestran en el esquema evolutivo de las fortificaciones (Fig. 21). La memoria que hemos seguido para su descripción incluía numerosos detalles técnicos de reparaciones puntuales de parapetos, troneras, limpieza de fosos, eliminación de obras provisionales del último sitio, muros de contención de tierras o rocas que se habían desprendido del Urgull ${ }^{79}$ en la parte del muelle ${ }^{80}$. También edificios militares, bóvedas a prueba de bomba, limpieza e igualación del glacis en la parte del hornabeque, etc.

79. Para mayor conocimiento del desarrollo de las construcciones del monte Urgull, cfr. Muñoz Echabeguren, F.: «Historia del monte Urgull: los últimos cien años», Boletín de Estudios Históricos sobre San Sebastián, 33, 1999, pp. 607-666.

80. Estado y Tanteo Prudencial de lo que podran importar las obras de fortificaciones de la Plaza de San Sebastian, su Castillo... Isidro Próspero de Verboom. 26 de enero de 1726. AGS. GM. Leg. 3432, p. 3. 


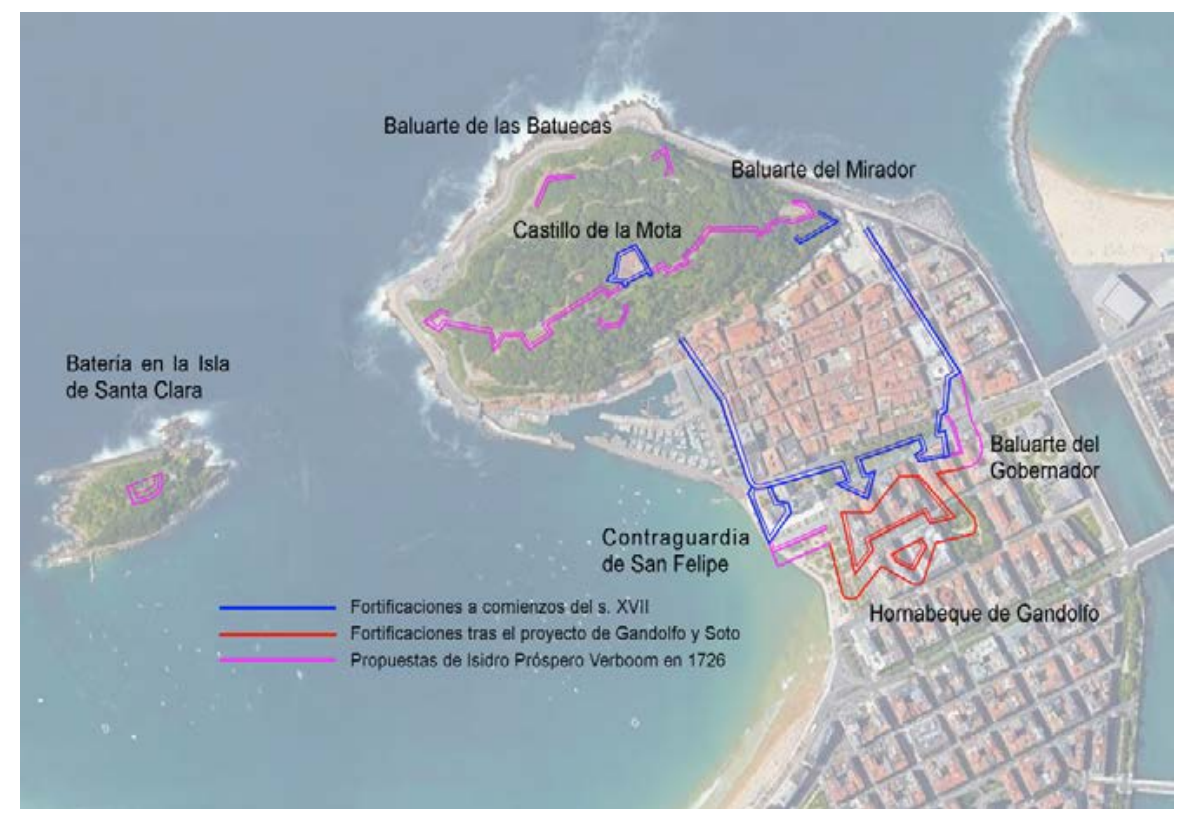

Figura 21. Evolución de las fortificaciones de San Sebastián (s. XviI-XviII) y proyecto de Isidro Próspero Verboom.

En cuanto a las obras proyectadas, podemos destacar que, al igual que su padre Jorge Próspero, que había aprendido según vimos de expertos como Vauban, van Coehoorn o Fernández de Medrano, Isidro no se dejaba llevar por formas regulares, simétricas o sacadas de tratadistas, sino que procuraba adaptarse al terreno en base a la experiencia de la profesión ${ }^{81}$. No es necesario hacer un elenco de estas disposiciones, que más bien estorbarían para un análisis de la trascendencia de lo proyectado por Isidro. Interesa más bien resaltar que este conjunto de obras -una lista larga y compleja- resultaba en su conjunto algo superior a lo necesitado en Fuenterrabía, pero muy inferior a lo requerido en Pamplona. San Sebastián crecía en importancia gracias a las posibilidades de su puerto, que sería más adelante Consulado del comercio $^{82}, \mathrm{y}$

81. Cfr. Cámara Muñoz, A.: «Les fortifications de la monarchie espagnole. Un système basé sur l'experience», en Warmoes, I.: Vauban, bâtisseur du Roi-Soleil. París, Somogy éditions d'art, 2007, pp. 48-54.

82. Cfr. Astiazaráin Achábal, M. I.: El Consulado de San Sebastián y los proyectos de ampliación de su puerto en el siglo XVIII. Donostia-San Sebastián, 1998, pp. 187-205. 
su proximidad con el puerto de Pasajes ${ }^{83}$. El presupuesto global ascendía a 250000 pesos, mientras que en Fuenterrabía Luis de Langot requería 193734 pesos para llevar a cabo el proyecto de Verboom ${ }^{84}$ (Fig. 23). En Pamplona, a pesar de que no ha quedado la memoria que Verboom padre debió de redactar, por informaciones de lo que se adeudaba en las tres plazas en agosto de 1726, podemos deducir que el presupuesto ascendía a unos 750000 pesos $^{85}$. Se trataba de una cantidad considerable. Hay que tener en cuenta que se construían tres fuertes exteriores avanzados de gran envergadura, todo el frente de Francia con dos baluartes bajos de gran escala más un revellín, y un hornabeque delante de la ciudadela hacia el suroeste. Además Jorge Próspero Verboom había proyectado un fuerte en la altura de Mendillorri y un campo atrincherado, amén de otras propuestas en la ciudadela ${ }^{86}$ (Fig. 22).

Podemos concluir que el centro neurálgico de la defensa de la frontera con Francia, en los Pirineos occidentales, era Pamplona, y a ella se destinaban la mayoría de los esfuerzos en fortificación. San Sebastián y Fuenterrabía eran plazas fuertes de segundo orden, y su defensa se ejercía en función del desarrollo de cada conflicto bélico ${ }^{87}$. En 1638, por ejemplo, se pudo levantar el sitio de Fuenterrabía por un apurado socorro, pero esto no sería factible en 1719. Las dos ciudades de la costa tenían una resistencia limitada en caso de sitio ante un ejército bien dotado de artillería y efectivos. Eran evidentes las dificultades que tendría un ejército en adentrarse desde estas plazas hacia el corazón de Castilla sin antes haber tomado Pamplona. Y sitiar la capital Navarra exigía una logística, un tren de artillería y

83. Para mayor conocimiento del conjunto de los enclaves fuertes de la costa de Guipúzcoa, véase SáEz García, J. A.: «Las fortificaciones costeras en Gipuzkoa (s. xvI-xx)», Itsas memoria: Revista de Estudios Maritimos del País Vasco, 6, 2009, pp. 113-132.

84. Tanteo hecho por el Ingeniero Director Dn.Luis de Langot, de las obras que por la mas precisas considera deverse executar en este presente año de 1726 en la Plaza de Fuenterrabía. 30 de diciembre de 1725. AGS. GM. Leg. 3432.

85. No es fácil deducir esta cantidad, pero podemos hacer a tenor de la memoria que el propio Verboom redactó en 1726 sobre las cantidades que se adeudaban en las tres plazas: En San Sebastián 49372 reales de plata, en Fuenterrabía 68 252, y en Pamplona 494 689. (Relacion de las obras de fortificaciones y otras empezadas en estas tres Plazas de Pamplona, San Sebastián y Fuenterrabía, que se podran continuar... Jorge Próspero Verboom. 21 de agosto de 1726. AGS. GM. Leg. 3453). Los tanteos de costes de obras de Pedro Moreau y Jaime Sicre, que las dirigieron una vez Verboom abandonó Pamplona a finales de 1726, van en la misma dirección. Jaime Sicre presupuestaba en 1736 para la finalización de las obras un total de 3002397 reales de plata, equivalentes a 375300 pesos.

86. Echarri Iribarren, V.: Las Murallas y la Ciudadela de Pamplona. Pamplona, 2000, pp. 426-427.

87. Cfr. CaPel, H.: «Los ingenieros militares y el sistema de fortificación en el siglo XVIII», en Cámara Muñoz, A. (coord.): Los ingenieros militares de la Monarquía Hispánica en los siglos XVI y XVII. Madrid, 2005, pp. 246-248. 
una superioridad de efectivos que no era fácil para el ejército francés. Su toma llevaría un prolongado periodo de tiempo, durante el cual se podría organizar sin problema un adecuado socorro. Tomar Pamplona y su ciudadela pentagonal tendría como objetivo una campaña orientada a la penetración en la Península, con todas sus consecuencias estratégicas. En cambio la toma de San Sebastián y Fuenterrabía -una empresa mucho más sencilla- formaría parte de la estrategia global de un conflicto bélico, en que se podrían intercambiar plazas fuertes en caso de negociaciones de paz.

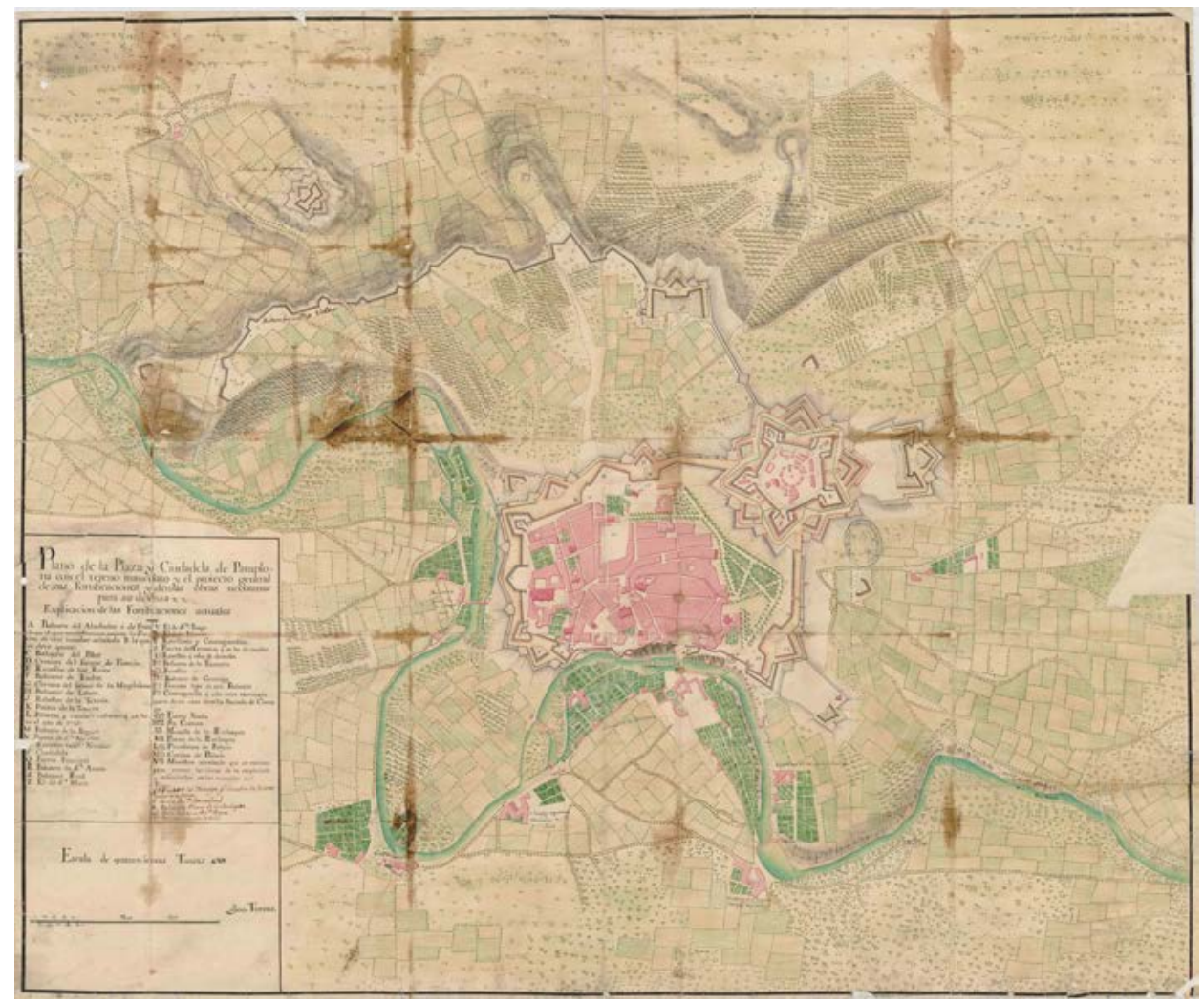

Figura 22. Proyecto General de Verboom para las fortificaciones de Pamplona. 28 de mayo de 1726. AGMM. NA-17/5. 


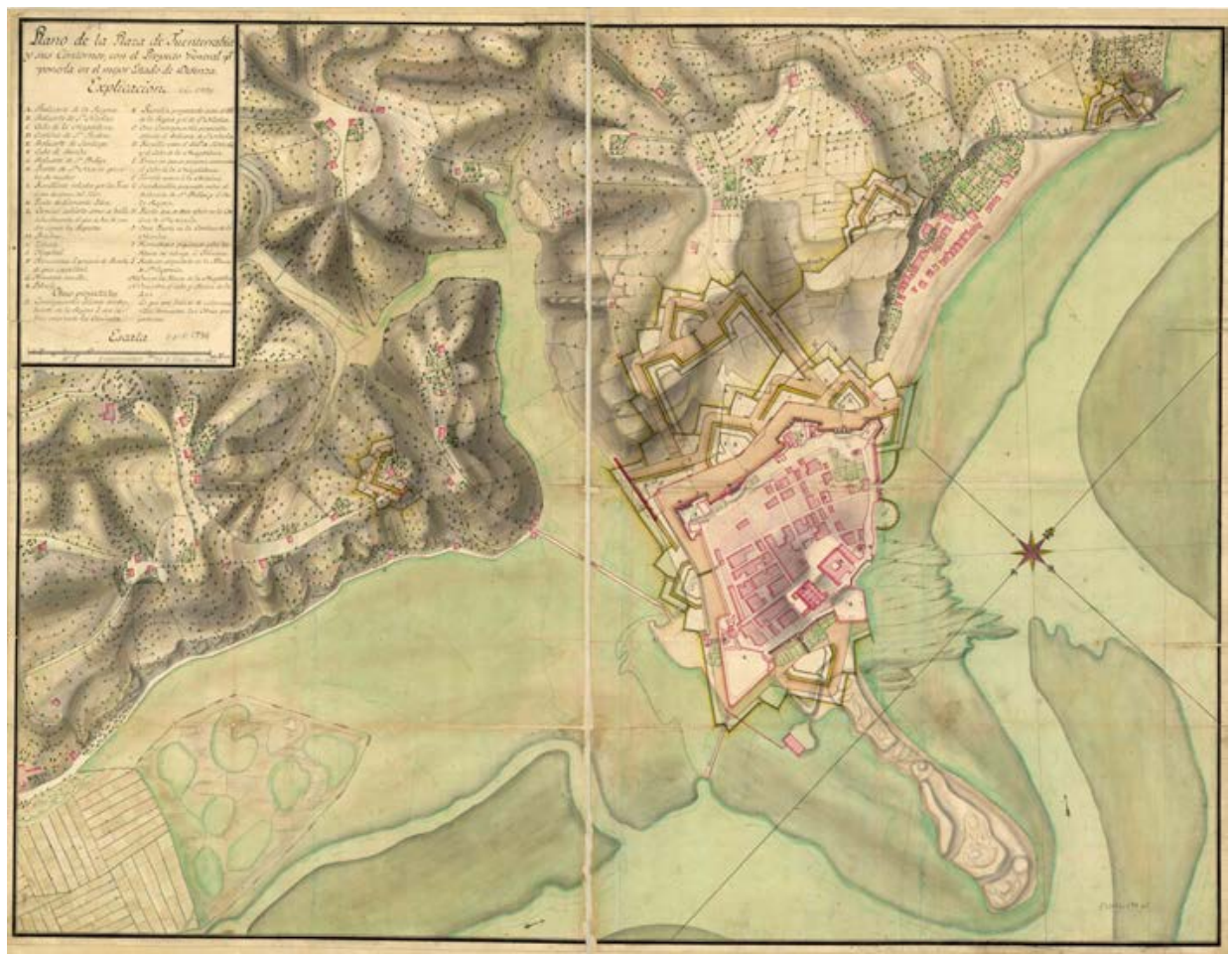

Figura 23. Proyecto final de Verboom. Agosto de 1726. Delineado por Pedro Moreau. CEGET. Ar.F-T.2-C.3-252.

El proyecto de Isidro Verboom era técnicamente perfecto, con una lograda economía de medios en concordancia con la importancia estratégica de la plaza. Era el proyecto con más amplitud gráfica, definición y precisión técnica de los que se habían redactado hasta la fecha. Su padre Jorge Próspero había puesto a su disposición todos los elementos técnicos más avanzados, así como el equipo humano que le acompañaba en sus viajes de inspección de fortificaciones desde 1721. Era el momento adecuado para preparar el futuro de Isidro Próspero como sucesor de su padre en el cargo de Ingeniero General. Tras otros trabajos en Santander o la Línea del Campo de Gibraltar, el rey aprobaría su nombramiento futuro como Ingeniero General en 1731. En 1733 ascendería a Brigadier y sustituto del Ingeniero General, pero su inesperada muerte truncaría su carrera hacia la cúspide de la ingeniería militar. 
VÍCTOR ECHARRI IRIBARREN

TERRITORIO Y SISTEMAS DEFENSIVOS DE FRONTERA: EL PROYECTO DE ISIDRO PRÓSPERO VERBOOM PARA LAS FOSTIFICACIONES DE SAN SEBASTIÁN EN 1726

\section{Conclusiones}

San Sebastián fue desde el nacimiento del bastión una plaza fuerte de importancia estratégica en la frontera hispano-francesa, junto con Fuenterrabía y Pamplona. Esta última fue siempre el centro de organización del territorio y del sistema defensivo, y por ello contó con un conjunto fortificado de primer orden, que Felipe II reforzó con la construcción de la primera ciudadela pentagonal en España. San Sebastián fue durante los siglos Xvi y xviI de menor importancia estratégica que Fuenterrabía. Sin embargo los problemas defensivos de la población del Bidasoa, unido al desarrollo del comercio del puerto de San Sebastián, hicieron que en el siglo xviII se apostara más por mejorar las fortificaciones de la ciudad del Urumea.

La defensa de San Sebastián se confiaba al castillo de la Santa Cruz de la Mota en el monte Urgull, reforzada con una batería dispuesta en la isla de Santa Clara. Las defensas de la ciudad hacia el sur consistían en el frente real de Carlos V, compuesto por el cubo Imperial y dos problemáticos baluartes a derecha e izquierda, y un hornabeque proyectado por Antonio Gandolfo en 1638. En el sitio que sufrió San Sebastián en 1719 a cargo del ejército francés las murallas se mostraron inoperantes. Era sin duda necesario acometer una revisión de las defensas.

En 1726 Isidro Próspero Verboom redactó un proyecto general para San Sebastián por orden de su padre Jorge Próspero Verboom. El proyecto era técnicamente perfecto, con una lograda economía de medios en concordancia con la importancia estratégica de la plaza. Reforzaba inteligentemente los puntos débiles de los baluartes del Gobernador y San Felipe, y hacía lo propio con el castillo de la Mota, con un conjunto de baterías extraordinario. Al tratarse de una buena roca la cimentación resultaba sencilla, y era difícil de minar. Además la batería de la isla de Santa Clara reforzaba la defensa tanto en la aproximación del enemigo por mar como por tierra, especialmente en la ascensión por el Urgull. El proyecto del baluarte del Mirador en sustitución del de los Jesuitas, garantizaba una mejor defensa, con ángulos de flanqueo adecuados para rechazar una aproximación desde la plaza, al tiempo que rechazaba las baterías que el enemigo podría emplazar en la Zurriola. Fue un proyecto con obras de fortificación de entidad media, que requirió un total de treinta y siete planos y unas detalladas memorias, un hecho desproporcionado y único en la historia de las fortificaciones españolas. Los realizó ayudado por el equipo de técnicos de su padre, logrando un alto estándar de precisión en la descripción del territorio y sus accidentes, así como en la delineación de las obras de fortificación proyectadas.

Esta desproporción entre la importancia estratégica de la plaza y el esfuerzo aplicado en el proyecto se debe al interés de Verboom padre en promocionar a su 
VÍCTOR ECHARRI IRIBARREN

TERRITORIO Y SISTEMAS DEFENSIVOS DE FRONTERA: EL PROYECTO DE ISIDRO PRÓSPERO VERBOOM PARA LAS FOSTIFICACIONES DE SAN SEBASTIÁN EN 1726

hijo como futuro Ingeniero General, exhibiendo sus credenciales como técnico experto en la materia. Verboom conseguiría su objetivo, y el rey Felipe V dispuso en 1731 que Isidro Próspero fuera quien sustituyera a su padre en el cargo de máximo responsable de las fortificaciones españolas y del Cuerpo de Ingenieros. Sin embargo, la inesperada muerte de Isidro Próspero Verboom en 1733 truncó las aspiraciones de la saga familiar.

\section{Bibliografía}

Artola, M.: Historia de Donosita-San Sebastián. San Sebastián, Ed. Nerea, 2004.

Astiazaráin Achábal, M. I.: «El Patrimonio Militar de Hondarribia: el Castillo de Carlos V y las Murallas», en Orella Unzué, J. L.: Historia de Hondarribia. Hondarribia, Hondarribiko Udala, 2004, pp. 477-482.

Astiazaráin Achábal, M. I.: El Consulado de San Sebastián y los proyectos de ampliación de su puerto en el siglo XVIII. Donostia-San Sebastián, Fundación Kutxa, 1998.

Bragard, Ph.: Dictionnaire biographique des ingénieurs des fortifications: Pays-Bas espagnols, principauté de Liège, Franche-Comté, 1504-1713. Namur, Amis de la Citadelle de Namur, 2011.

Cámara Muñoz, A.: «Les fortifications de la monarchie espagnole. Un système basé sur l'experience», en Warmoes, I.: Vauban, bâtisseur du Roi-Soleil. París, Somogy éditions d'art, 2007, pp. 48-54.

CÁmara Muñoz, A.: «Murallas para la guerra y para la paz. Imágenes de la ciudad en la España del siglo XvI», Espacio, Tiempo y Forma, Serie VII, $\mathrm{H}^{\mathrm{a}}$ del Arte, t. 6, 1993, pp. 149-174.

Cámara Muñoz, A.: «Tiburzio Spannocchi, Ingeniero Mayor de los reinos de España», Espacio, Tiempo y Forma, Serie VII, 2, 1988, pp. 77-90.

Cámara Muñoz, A.: «La Corona de Castilla», en Hernando Sánchez, C. J. (coord.): Las Fortificaciones de Carlos V. Madrid, Ministerio de Defensa; Asociación Española de Amigos de los Castillos; Sociedad Estatal para la Conmemoración de los Centenarios de Felipe II y Carlos V, DL, 2000, pp. 415-439.

CAPEL, H.: «Los ingenieros militares y el sistema de fortificación en el siglo XVIII», en Cámara Muñoz, A. (coord.): Los ingenieros militares de la Monarquía Hispánica en los siglos XVI y XVII. Madrid, Ministerio de Defensa, 2005, pp. 231-267.

CAPEL, H. et al.: Los ingenieros militares en España, siglo XVIII. Repertorio bibliográfico $e$ inventario de su labor cientifica y espacial. Barcelona, Ediciones y Publicaciones de la Universidad de Barcelona (Colección «Geocrítica. Textos de Apoyo»), 1983.

Capel, H., Sánchez, J. E. y Moncada, O.: De Palas a Minerva. La formación científica y la estructura institucional de los ingenieros militares en el siglo XVIII. Madrid, Barcelona, CSIC, Serbal, 1988.

Chafrión, I.: Escuela de Palas o sea Curso Mathematico dividido en XI tratados, que contienen la Arithmetica, Geometria Speculativa... y ultimamente el Arte Militar. Tomo 2. Milan, Imprenta Real, por Marcos Antonio Pandulpho Malatesta, 1693. 
VÍCTOR ECHARRI IRIBARREN

TERRITORIO Y SISTEMAS DEFENSIVOS DE FRONTERA: EL PROYECTO DE ISIDRO PRÓSPERO VERBOOM PARA LAS FOSTIFICACIONES DE SAN SEBASTIÁN EN 1726

Cobos Guerra, F.: «La fortificación española en los siglos xvir y xviII: Vauban sin Vauban y contra Vauban», en Silva SuÁrez, M. (ed.): Técnica e ingeniería en España. El siglo de las luces. Vol. II. Madrid, Real Academia de Ingeniería, Institución «Fernando el Católico», Zaragoza, Prensas Universitarias de Zaragoza, 2005, pp. 469-520.

Cobos Guerra, F. y Castro Fernández, J. J. de: «Diseño y desarrollo técnico de las fortificaciones de transición españolas», en Hernando Sánchez, C. J. (coord.): Las Fortificaciones de Carlos V. Madrid, Ministerio de Defensa; Asociación Española de Amigos de los Castillos; Sociedad Estatal para la Conmemoración de los Centenarios de Felipe II y Carlos V, DL, 2000, pp. 218-243.

ECharri Iribarren, V.: «Territorio, inundaciones y defensa en Flandes: los proyectos de Verboom y Vauban para las fortificaciones de Lier en 1702», Hispania. Revista Española de Historia, 78:258, 2014, pp. 139-167.

Echarri Iribarren, V.: «Jorge Próspero de Verboom General Project for the Fortifications of Pamplona in 1726», SGEM 2014 International Multidisciplinary Conferences on Social Sciences and Arts, 1-9 September 2014, Albena, Bulgaria, 2014, pp. 897-908.

Echarri Iribarren, V.: «El Proyecto de Jorge Próspero Verboom para las Fortificaciones de Fuenterrabía», Tiempos Modernos. Revista Electrónica de Historia Moderna, 8:34, 2017, pp. 202-233.

ECHARri Iribarren, V.: «El proyecto general para las fortificaciones de Alicante en 1721», Hispania. Revista Española de Historia, 74:247, 2014, pp. 411-438.

Echarri Iribarren, V.: Las Murallas y la Ciudadela de Pamplona. Pamplona, Departamento de Educación y Cultura-Institución Príncipe de Viana, Gobierno de Navarra, 2000.

Echarri Iribarren, V.: «El proyecto de Juan Martín Zermeño para las fortificaciones de Pamplona: una revisión del Proyecto General de Verboom», Tiempos Modernos. Revista Electrónica de Historia Moderna, 8:30, 2015, pp. 426-457.

Echarri Iribarren, V. y Yáñez Pacios, R. T.: «Bastión y ciudad: Los proyectos para las fortificaciones de Fuenterrabía a finales del siglo XvI», Tiempos Modernos. Revista Electrónica de Historia Moderna, 8:32, 2016, pp. 88-124.

Elizalde Marquina, E.: Pamplona plaza fuerte. 1808-1973. Del derribo a símbolo de identidad de la ciudad. Pamplona, Ayuntamiento de Pamplona, 2012.

Faucherre, N.: Places fortes, bastion du pouvoir. París, Nouv. éd. Rempart, 1989.

Fernández Antuña, C. M.: Murallas de Hondarribia. De la cerca medieval al recinto abaluartado. Hondarribia, Antza, 2003.

Fernández Antuña, C. M.y Ayerbe Irízar, M.: «Sondeos arqueológicos en el Boulevard (1993): El Frente de Tierra de las fortificaciones de San Sebastián (s. Xvi)», Boletín de Estudios Históricos sobre San Sebastián, 28, 1994, pp. 741-766.

Fernández de Medrano, S.: El arquitecto perfecto en el Arte Militar: Dividido en cinco libros. El $1^{\circ}$ contiene la fortificación regular e Irregular a la Moderna... Bruselas, Casa de Lamberto Marchant, 1700.

Galland Seguela, M.: Les Ingénieurs Militaires Espagnols de 1710 à 1803. Madrid, Bibliothèque de la Casa de Velázquez, vol. 40, 2008.

Ediciones Universidad de Salamanca / @థ®요 Stud. his., H. ${ }^{a}$ mod., 40, n. 1 (2018), pp. 361-403 
VÍCTOR ECHARRI IRIBARREN

TERRITORIO Y SISTEMAS DEFENSIVOS DE FRONTERA: EL PROYECTO DE ISIDRO PRÓSPERO VERBOOM PARA LAS FOSTIFICACIONES DE SAN SEBASTIÁN EN 1726

Gómez Piñeiro, F. J. y Sáez García, J. A.: Documentos cartográficos Históricos de Gipuzkoa: II Servicio Histórico Militar. Donostia-San Sebastián, Diputación Foral de Gipuzkoa, 1999.

Jiménez Moreno, A.: «Opciones estratégicas de la Monarquía Española a comienzos de la guerra contra Francia (1635-1638): la propuesta de Marco antonio Gandolfo», Chrónica Nova, 38, 2012, pp. 177-202.

Llave y García, J. de la: «Don Jorge Próspero de Verboom. Marqués de Verboom», Memorial de Ingenieros, 28, 1911, pp. 109-160.

Llave y García, J. de la: «Don Sebastián Fernández de Medrano, como escritor de fortificación», Memorial de Ingenieros, Madrid, 33:15, 1878, pp. 113-115

Mantecón Movellán, T. A. y Truchuelo García, S.: «Las frontera exteriores e interiores de la Monarquía Hispánica: perspectivas historiográficas», Historia Crítica, 59, 2016, pp. 19-39.

Martinena Ruiz, J. J.: La Pamplona de los Burgos y su evolución urbana. Pamplona, Diputación Foral de Navarra, Institución Príncipe de Viana, 1974.

Mexía Carrillo, F.: El castillo de Santa Cruz de la Mota y las murallas de la Plaza de San Sebastián. San Sebastián, Grupo Dr. Camino de Historia donostiarra, 1979.

Muñoz Corbalán, J. M.: Jorge Próspero Verboom. Ingeniero militar flamenco de la monarquía hispánica. Madrid, Fundación Juanelo Turriano, 2015.

Muñoz Corbalán, J. M.: Los Ingenieros Militares de Flandes a España (1691-1718). Tomo I. Madrid, Centro de Publicaciones del Ministerio de Defensa, 1993.

Muñoz Echabeguren, F.: «Historia del monte Urgull: los últimos cien años», Boletín de Estudios Históricos sobre San Sebastián, 33, 1999, pp. 607-666.

Olavide, J., Albarellos, B. y Vigón, J.: San Sebastián. Historia de sus fortificaciones. Siglos XVI y XVII. El sitio de 1813. San Sebastián, Ayuntamiento de San Sebastián, 1963,360 p.

OrgeIx, É. d': «Al servicio del rey. El espionaje francés de las plazas fuertes españolas en el siglo XVII», en Cámara MuÑoz, A. (coord.): Los ingenieros militares de la Monarquía Hispánica en los siglos XVI y XVII. Madrid, Ministerio de Defensa, 2005, pp. 97-111.

Pereda, F. y Marías, F.: «De la cartografía a la corografía: Pedro Texeira en la España del Seiscientos», Ería, 64-65, 2004, pp. 129-157.

Porras GIL, C.: La Organización Defensiva Española en los siglos XVI-XVII. Desde el río Eo hasta el Valle de Arán. Valladolid, Secretariado de Publicaciones, Universidad de Valladolid, 1995.

Quatrefages, R.: «La fortificación en España durante el Renacimiento (II)», Ejército, febrero 1984, pp. 69-75.

Rocolle, P.: 2000 ans de fortification française. Vol. 2. Du 16e siècle au mur de l'Atlantique. París, Lavauzelle, 1989.

Rodríguez Villa, A.: «Don Sebastián Fernández de Medrano. Director de la Real Academia Militar de Bruselas (1646-1705)», Revista Contemporánea, Madrid, 147, 1882, pp. 1-27. 
VÍCTOR ECHARRI IRIBARREN

TERRITORIO Y SISTEMAS DEFENSIVOS DE FRONTERA: EL PROYECTO DE ISIDRO PRÓSPERO VERBOOM PARA LAS FOSTIFICACIONES DE SAN SEBASTIÁN EN 1726

Roldán, J. M., Sáez, J. A., Piñeiro, J. G., Orella J. L. y Aramburu, J. M. Documentos cartográficos históricos de Gipuzkoa: I Servicio Geográfico del Ejército. San Sebastián, Diputación Foral de Gipuzkoa, 1994.

Ruiz Oliva, J. A.: Fortificaciones Militares de Ceuta: siglos XVI al XVIII. Ceuta, Instituto de Estudios Ceutíes, 2002, 504 p.

SÁEz GarcíA, J. A.: Gotorlekuak Gipuzkoan XVI-XIX mendean. Fortificaciones en Guipúzcoa siglos XVI-XIX. Donostia, Gipuzkoako Foru Aldundia, 2002.

SÁez García, J. A.: Viejas piedras: fortificaciones guipuzcoanas. San Sebastián, Michelena, 2000, $276 \mathrm{p}$.

SÁEz García, J. A.: «Fortificaciones liberales en el entorno de San Sebastián en la última Guerra carlista», Boletín de Estudios Históricos sobre San Sebastián, 35, 2001, pp. 255-327.

Sáez García, J. A.: «La galería de tiro del monte Urgull (San Sebastián)», Boletín de Estudios Históricos sobre San Sebastián, 37, 2003, pp. 353-398.

Sáez García, J. A.: "Las fortificaciones costeras en Gipuzkoa (s. XVI-XX)», Itsas memoria: Revista de Estudios Marítimos del País Vasco, 6, 2009, pp. 113-132.

Tellechea Idígoras, J. I.: El asedio de San Sebastián (1719) por el Duque de Berwick: una guerra dentro de otra guerra. Donostia-San Sebastián, Kutxa Fundazioa, 2002.

Truchuelo García, S.: «Fronteras marítimas de la Monarquía de los Habsburgo: el control de la costa cantábrica», Manuscrits. Revista de Hitòria Moderna, 32, 2014, pp. 33-60.

Tzonis, A. y Lefaivre, L.: «El bastión como mentalidad», en Seta, C. De; Le Goff, J. (eds.): La ciudad y las murallas. Madrid, Cátedra, 1991, pp. 317-340.

Vauban, S. le P.: Traité des Siéges sur L'attaque et La Defense des Places de Guerre Par Monsieur De Vauban... La Haya, Chez Pierre de Hondt, 1737.

Vauban, S. le P.: Veritable Manière de Fortifier de Mr. de Vauban. Où l'on voit de quelle méthode on se sert aujourd'bui en France... Tomo II. Amsterdam, Chez Pierre Mortier, Paris, 1689.

VIganò, M.: "El fratin mi ynginiero». I Paleari Fratino da Morcote ingegneri militari ticinesi in Spagna (XVI-XVII secolo). Bellinzona, Edizioni Casagrande, 2004.

Warmoes, I.: «Vauban et l'art de la fortification», en Warmoes, I. (coord.): Vauban, bâtisseur du Roi-Soleil. Catálogo de la exposición organizada por la Cité de l'architecture et du patrimoine, Paris, 14 de noviembre de 2007-5 de febrero de 2008, París, Somogy éditions d'art, 2007, pp. 190-197.

Wauwermans, H.: El Marqués de Verboom, ingeniero militar flamenco al servicio de España, Traducido del francés y adicionado con notas recogidas por el difunto coronel de ingenieros D. Mariano Bosch y Arroyo, por el coronel Graduado D. Joaquin de la Llave y García. Madrid, Imprenta de Memorial de Ingenieros, 1894. 